\title{
Looking for Urban Agency in a City of Memorials: Tomb Towers of Late Thirteenth-Century Ahlat
}

\author{
Oya Pancaroğlu*
}

In the medieval period, the city of Ahlat was an important urban center in the Lake Van region. The medieval city suffered serious depredations in the form of military assaults and earthquakes between the 13th and the 16th centuries that caused the urban center to be rebuilt at least twice at some distance from the medieval location. While only meager traces of the medieval urban fabric remain, Ahlat preserves a remarkable medieval funerary landscape of cemeteries and tomb towers that attest to the dynamic workings of local urban agency. This essay focuses on a discrete set of tomb towers of the late thirteenth century built by Muslim amirs of the Ilkhanate in order to explore the relationship between these new urban actors and the physically elusive urban stage of medieval Ahlat, in tandem with contemporary political circumstances. These tomb towers - built in the outskirts of the medieval city in the aftermath of much destruction witnessed in the course of the thirteenth century - represent some of the earliest indications of Islamization among Ilkhanid amirs but have hitherto been studied from a purely formalistic angle. In order to situate these monuments in their historical context, the essay is grounded in an extended summary of the medieval (7th13th centuries) political and military history and the attendant demographic changes that significantly impacted the urban structure of Ahlat. The construction of tomb towers is investigated in the light of the compromised nature of the thirteenth-century urban settlement and the contemporary emergence of nodes of Sufi inhabitation in the peripheries of Ahlat as can be deduced from Ottoman-period tax registers. Amounting to a spatial externalization of urban agency, the tomb towers and Sufi lodges represent distinct but complementary claims to reconstitute social and political influence in the face of a ruptured urban center.

Keywords: Ahlat, Lake Van, Ilkhanate, Islamization, Tomb towers

* Correspondence details: Department of History, Boğaziçi University, Bebek 34342, Istanbul, Turkey, oya. pancaroglu@boun.edu.tr

This article is part of the themed section Urban Agencies: Reframing Anatolian and Caucasian Cities (13th-14th Centuries), guest editors: Bruno De Nicola and Matthew Kinloch. To read all related articles, please access: dx.doi. org/10.1553/medievalworlds_no14_2021. 
The monuments of the dead still stand, and have become the monuments of a city, itself long crumbled into dust. Amidst orchards and gardens are scattered here and there low houses rudely built out of the remains of the earlier inhabitations, and fragments of cornice and sculpture are piled up into walls around the cultivated plots. ${ }^{1}$

Modern Ahlat is spread out over a distance of about five kilometers along the northwest shoreline of Lake Van. Its ancient to medieval urban center is situated less than two kilometers inland from the lakeshore and marked by the scanty remains of a citadel. In the sixteenth century, a new Ottoman fortress was built two kilometers further east by the lakeshore, effectively breaking with the medieval citadel and city. By the nineteenth century, however, this Ottoman fortress had also lost its appeal and function, while a new administrative and commercial center emerged about two kilometers further east. Very little remains of the medieval urban fabric of Ahlat located at the western reaches of this extended settlement, a result no doubt of destructive earthquakes and recurrent assaults, especially between the thirteenth and sixteenth centuries. In contrast to the loss of evidence for the medieval living city, an extensive and famed funerary landscape with thousands of intricately carved tombstones, hundreds of underground burial chambers and dozens of tomb towers are the main clues to the significance of Ahlat during the same period.

Of these, the tomb towers have been documented more thoroughly in terms of their architecture and inscriptions. Yet, such studies have not ventured much beyond formal description and no attempt has been made to discern broader patterns of patronage or of construction nor to synthesize the findings into a historically contextualized set of observations that may shed light on the urban history of medieval to early modern Ahlat. This essay seeks to focus on a discrete set of tomb towers of the late thirteenth century associated with the Muslim amirs of the Ilkhanate in order to explore the relationship between these urban actors and the physically elusive urban stage of medieval Ahlat, in tandem with contemporary political circumstances.

\section{Ahlat from the Seventh to the Thirteenth Century}

According to the ninth-century historian al-Balādhurī, Ahlat (Armenian Xlat', Arabic Khilāt, Persian and Ottoman Turkish Akhlāt) capitulated to the Arab-Muslim forces as early as 640 in a campaign into northern Mesopotamia led by the commander 'Iyād b. Ghanm. ${ }^{2}$ The terms of Ahlat's capitulation, negotiated with its Armenian prince (batriq $)$, were the standard taxes of jizya (poll tax) and kharäj (land tax), the responsibility for which was given to the lord (șähib) of nearby Bitlis (Arabic Badliss, Armenian Baghesh) (Fig. 1). This was the tail end of the campaign of 640 and al-Balādhurī noted that 'Iyāḍ b. Ghanm did not push much further into Armenia but returned to his governorship in Homs. Although al-Balādhurī did not employ

1 Layard, Discoveries, 23.

2 For the history of Ahlat, see Bosworth, Akhlāț; Minorsky and Taeschner, Aknhlāț; Sümer, Ahlat. On the campaign of 640, see al-Balādhurī, Origins of the Islamic State, 275. 
the Armenian toponym, it seems clear that it was the district of Bznunik', extending approximately from Bitlis in the west to Adilcevaz (Artske in Armenian) to the east of Ahlat, that constituted the northeastern limit of 'Iyād b. Ghanm's northern Mesopotamian campaign. The toponym Bznunik' was applied not only to these areas surrounding the northwestern quadrant of Lake Van but also formed the common Armenian designation of the lake as Bznuniats Dzov (»Sea of Bznunik'«). ${ }^{3}$

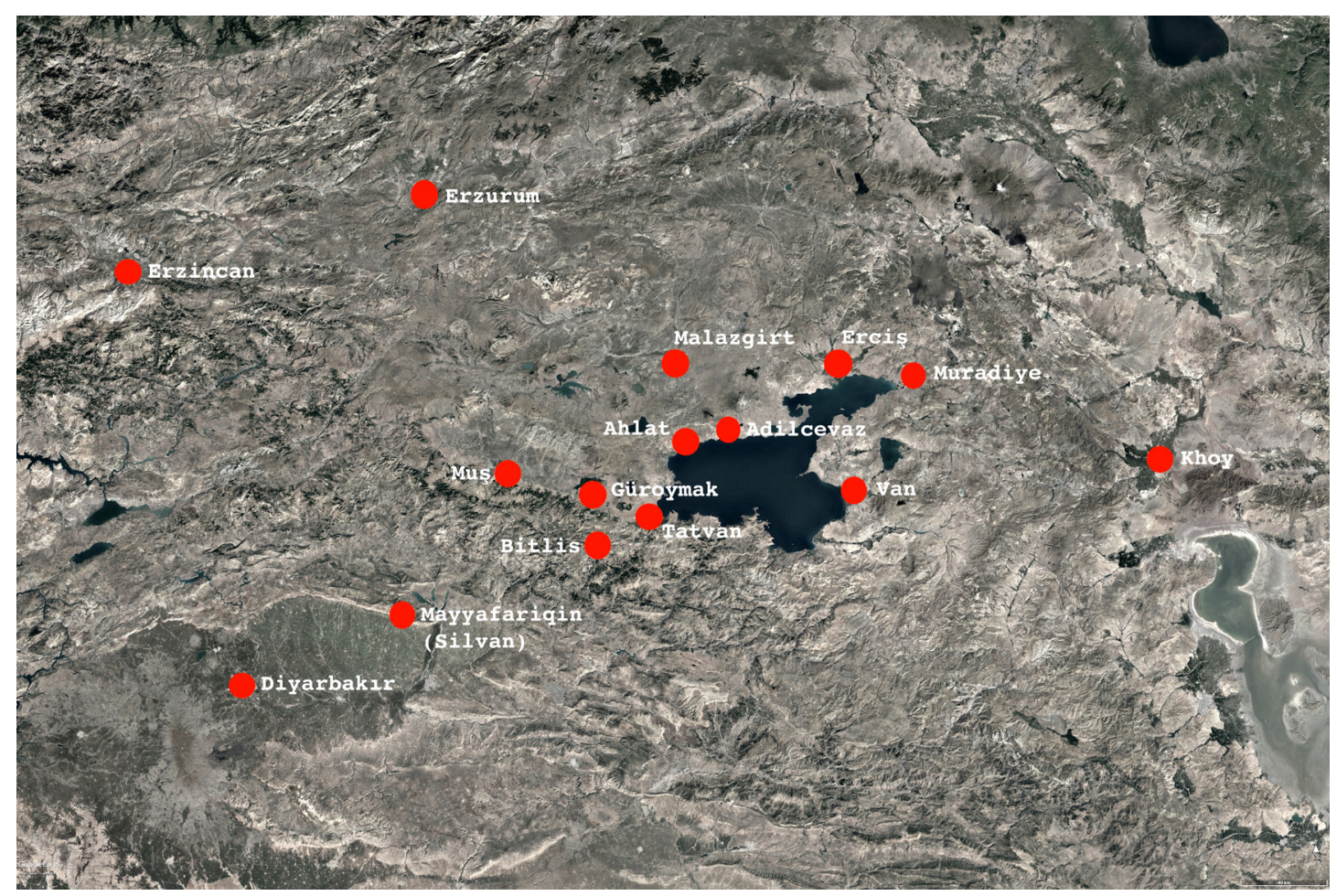

Fig. 1: Map indicating cities mentioned in the text (Source: Google Earth view, 30 September 2019)

Arab-Muslim military incursions deeper into Armenia continued in the 640 s and 650 s, in the context of the conflict between Byzantium and the nascent Islamic state. Formal annexation and direct control came at the end of the century, in the aftermath of the Second Civil War, when the Umayyad caliph 'Abd al-Malik appointed his brother Muhammad b. Marwān as governor and effectively created the province of Arminiya in a brutal process of subjugation. ${ }^{4}$ Rebellions led by Armenian princes recurred from the Umayyad into the Abbasid period and culminated in the devastating Battle of Bagrevand in 775 that triggered the decline and disappearance of a number of prominent Armenian princely families. This was followed by a wave of Arab tribal settlement, especially north of Lake Van, which formed into a number of Muslim emirates. ${ }^{5}$ Although it is probable that towns like Ahlat maintained a majority

3 On the toponym Bznunik', see Hübschmann, Ortsnamen, 328-329 and Ananias, Geography, 48.

4 Garsoïan, Arab invasions, 125-127 and Canard et al., Arminiya.

5 Garsoïan, Arab invasions, 134-135. 
Armenian population through the ninth century, demographic change towards Islamization was already underway. When the Abbasid caliph al-Mutawakkil sent Bughā al-Kabīr to crush the Armenian rebellion of 850-55, the Abbasid armies were divided in Ahlat and directed from there to other regions, ${ }^{6}$ suggesting that Ahlat was recognized as a secure Muslim center by the mid-ninth century.

With Abbasid decline and political fragmentation in the tenth century, Ahlat passed into the control of the Arab Hamdānid dynasty in 939 but, by 983 it had become part of the possessions of the Kurdish Marwānid dynasty based at Āmid (modern Diyarbakır) and Mayyāfāriqinn (Syriac Mayperqit, Greek Martyropolis, Armenian Np'rkert, modern Silvan). ${ }^{7}$ It was during the long and stable reign of the Marwānid ruler Nașr al-Dawla (r. 1011-1061) that the eastern Iranian poet-philosopher Nāșir-i Khusraw visited Ahlat in 1045 and described it as a "border town between Muslims and Armenians" in which Arabic, Persian and Armenian were the common languages. ${ }^{8}$ The Armenian lands to the north and the south (Vaspurakan) had been annexed by the Byzantine Empire earlier in the century but Ahlat remained tied to the Marwānid establishment, which maintained largely peaceful relations with the Byzantines and astutely managed the initial Seljuq incursions into the region under Tughrul Beg in 1056-1057. ${ }^{9}$

Thus, in the four centuries following the initial capitulation to the Arab-Muslim forces, Ahlat developed into a base for a succession of Muslim authorities but did not outshine other nearby towns such as Bitlis or Mayyāfäriqin. This situation changed in the aftermath of the Battle of Manzikert (1071) when it became the seat of a new dynasty established by a Seljuq military officer of slave background named Sukmān al-Quṭì (r. 1100-1112) whose chosen regnal appellation, as that of his successors, was Shāh-i Arman ("King of Armenia« or "King of Armenians"), a plain reflection of continued Armenian demographic predominance in the region. ${ }^{10}$ The territories controlled by the Shāh-i Arman extended from Muş and Mayyāfäriqin in the west to Bārgīrì (Armenian Berkri, modern Muradiye) and Van in the east and Malāzgird (Armenian Manazkirt, modern Malazgirt) in the north. ${ }^{11}$ During the long reign of Sukmān II (r. 1128-1185), the sphere of Shāh-i Arman influence was extended further east, as evinced by mentions of an eponymous Sukmānābād on the road to Khoy. ${ }^{12}$ The Armenian historian Vardan Arawelts'i praised Sukmān II as a ruler who was »friendly to Christians«

10 On the history of the Shāh-i Arman dynasty, see Hillenbrand, Sֵhāh-i Arman; Sümer, Ahlatşahlar; Turan, Doğu Anadolu, 101-129; Sümer, Doğu Anadolu'da Türk Beylikleri, 67-85. Although the title Shāh-i Arman is often understood to mean »King of Armenians «, contemporary usage of Arman could denote both "Armenia« and "Armenians." The title Shāh-i Arman outlived the dynasty established by Sukmān al-Quṭbī as it is found in Ayyūbid inscriptions in nearby Mayyāfäriqin; Gabriel, Şarki Türkiye’de Arkeolojik Geziler, 271, 273; Eastmond, Tamta’s World, 134.

11 Turan, Doğu Anadolu, 104.

12 Sinclair, Eastern Turkey, 269; Hillenbrand, Muslim Principality, 120. By 1118, Mayyāfāriqīn had passed into Artuqid control. 
and who "preserved [the land] in deep peace for sixty years. ॥ $^{13}$ The reign of Sukmān II constituted the highpoint of the dynasty with accretion of wealth due both to trade revenues and to military campaigns directed, in alliance with other Turkic dynasties, against the Georgian kingdom. ${ }^{14}$ In the aftermath of a particularly lucrative military campaign against the Georgians in the summer of 1163, Sukmān II's Saltukid wife, Shāh Bānū, initiated a major building spree in 1164, likely financed by the booty gained from the Georgian side. ${ }^{15}$ In addition to a complete overhaul of the citadel, Shāh Bānū is said to have ordered the construction of a number of caravanserais and rebuilt numerous wooden bridges out of stone. ${ }^{16}$

After Sukmān II's death, with no offspring to succeed him, the throne was claimed by a succession of slave amirs, starting with Sayf al-Dīn Begtimūr (r. 1185-1193). The only Shāh-i Arman ruler known to have struck a coin in his own name, Begtimūr nonetheless acknowledged the dominance of Saladin and the ascent of the Ayyubids in Syria and Egypt. Towards the turn of the thirteenth century, Ahlat was caught in the middle of mounting tensions between the Ayyubids and the Seljuq Atābegs of Azerbaijan. This, combined with campaigns of the resurgent Georgian kingdom moving as far south as the Lake Van region, eventually spelled the end of the dynasty of the Shāh-i Arman and Ahlat, along with Erciş (Arabic Arjīsh, Armenian Archēsh), Malazgirt and Van, came into Ayyubid possession in 1207-8. ${ }^{17}$

Al-Malik al-Awhad, the Ayyubid prince charged with seizing these cities, was immediately confronted with widespread rebellion in the region that appears to have been initiated in Ahlat and was eventually suppressed with brutal measures. Soon after regaining control of Ahlat, al-Awhad had to tackle the recurrent Georgian threat in the region. In 1210, an attempted Georgian siege of Ahlat resulted in the Ayyubid capture of Ivane Mqargrdzeli, chief military commander from the Armenian Zakarian family in the service of the Georgian court. This unexpected turn of events allowed al-Awhad to negotiate a thirty-year truce and the hand of Ivane's daughter, T'amt'a, in return for the release of the high-profile captive. When al-Awhad died very soon afterwards, it was his brother al-Malik al-Ashraf who came into possession of Ahlat and the region of Lake Van and also married his late brother's wife, T'amt'a.

In the next decade, however, Ayyubid Ahlat once again became a military target, this time of the Khwārazmshāh Jalāl al-Dīn Mangburnī (r. 1220-1231) who laid siege to the city twice, once in 1226 and again in 1229-30. The Ayyubid governor of the city, the chamberlain Husām al-Dīn 'Alī, successfully deflected the first siege, with the participation of citizens. ${ }^{18}$ The second Khwārazmshāh siege, however, lasted a phenomenal eight and a half months (from late August 1229 to mid-April 1230) and, when the city finally fell, extensive massacres, pillaging and destruction took their toll. This brutal Khwārazmshāh assault left Ahlat as a shadow of

13 Thomson, Historical compilation, 204.

14 Peacock, Georgia and the Anatolian Turks, 128-133.

15 On the description of this booty, see Minorsky, Studies, 93-94.

16 Turan, Doğu Anadolu, 135-136.

17 On Ayyubids in Ahlat and in Armenia, see Minorsky, Studies, 146-156; Demir, Ahlât Eyyûbîleri.

18 Ibn al-Athïr, Chronicle, trans. Richards, 276-277. 
its former self, while the population was decimated as those who escaped the massacres and enslavement abandoned their city. ${ }^{19}$ T'amt'a was apparently taken captive while her husband, al-Ashraf, remained focused on his new possession of Damascus. ${ }^{20}$ An alliance struck between the Rum Seljuqs and the Ayyubids finally routed the army of Jalāl al-Din Mangburnì in the Battle of Yassiçemen in Anatolia in August 1230 and ended the Khwārazmshāh threat.

Ahlat appears to have recuperated some semblance of urban life in the aftermath of the violence of 1229-30. The Rum Seljuqs occupied the city in 1233 when, according to the historian Ibn Bībì, reconstruction activities were begun on the order of the Rum Seljuq sultan 'Alā al-Dīn Kayqubād. ${ }^{21}$ Ibn Bībì related that 'Alā al-Dīn Kayqubād took the decision to send his amir Kamāl al-Dīn Kāmyār to Ahlat as a response to increasing Mongol presence in the region $^{22}$ and the failure of al-Ashraf, ensconced and aloof in Damascus since 1229, to take care of the "lands of Armenia " (diyār-i Arman). Indeed, Armenian sources indicate that Ahlat had been subject to Mongol raiding activity as early as $1232 .{ }^{23}$ Thus, Kamāl al-Dīn Kāmyār was tasked with initiating the process of the annexation and rebuilding of the diyarr-i Arman, ostensibly "from Akhlāt and Bidlīs to the districts of Tiflis." Ahlat was made into the base of Rum Seljuq operations, which were continued by a team of administrators and military officers who were sent to the city to set up a regional government and revive both urban and rural life. This Rum Seljuq intervention, however, was cut short when Mongol raiding activity shifted to the region of Erzurum and, according to Ibn Bỉbì, caused an anxious Rum Seljuq governor and his officers in Ahlat to abandon their position abruptly in 1234, lest they be cut off from the sultanate. Although it is not very clear who precisely remained in charge in Ahlat during the tumultuous events of the next several years, ${ }^{24}$ it would appear that the Rum Seljuqs could not muster the capacity to keep Ahlat or the region, which came under Ayyūbid control once more. ${ }^{25}$ Mongol incursions into Anatolia culminated with their victory at the Battle of Kösedağ in 1243 and the transformation of the Rum Seljuq sultanate into a Mongol vassal state.

19 Ibn al-Athï, Chronicle, trans. Richards, 297-298.

20 Humphreys, Saladin to the Mongols, 218.

22 Mongol forces, under the leadership of the commander general Chormaghan were based in Azerbaijan from 1230; Dashdondog, The Mongols and the Armenians, 55.

23 Dashdondog, The Mongols and the Armenians, 55.

24 These events included the Ayyübid attempt to invade Anatolia in 1234 (Humphreys, From Saladin to the Mongols, 223-227), the unexpected deaths of Sultan 'Alā al-Dīn Kayqubād and al-Malik al-Ashraf in the summer of 1237, the »reign of terror « instigated by the amir Sa'd al-Din Köpek that resulted in the murder of much of the top echelon of Rum Seljuq amirs and statesmen in the early part of Sultan Ghiyāth al-Dīn Kaykhusraw II's reign and, last but not least, the uprising known as the Bābā'ì Revolt of 1240 directed against the Rum Seljuq establishment.

25 Demir, Ahlât Eyyûbîleri, 206-218. 
In 1244, Mongol forces, commanded by Baiju Noyan, captured Ahlat along with Harran and al-Ruhā (Edessa, modern Urfa). ${ }^{26}$ Ahlat was then handed over to T'amt'a, who, freed from Khwārazmshāh captivity after Yassıçemen, evidently returned to Georgia and subsequently spent some nine years as a royal hostage at the Mongol court in Karakorum. ${ }^{27}$ Muslim sources mention that, upon being installed in Ahlat by Mongol decree in 1245, she sought the hand of Shihāb al-Dīn Ghāzì, the last Ayyubid ruler of Mayyāäariqīn, but he seems not to have accepted the offer. ${ }^{28}$ Although there is no concrete information on conditions in Ahlat during T'amt'a's tenure, Armenian sources indicate that she was a generous patron, especially of Christian pilgrims and inhabitants. ${ }^{29}$ There is also no precise information on the duration of her position in Ahlat but it is assumed that she probably died around the mid- 1250 s, ${ }^{30}$ possibly just before or around the sacking of Baghdad and the establishment of the Ilkhanate by the Chinggisid scion Hülegü in 1258.

In the following year, Hülegü launched the Mongol invasion of Syria, reaching as far south as Palestine. Upon his withdrawal from Syria and return to Azerbaijan, Hülegü stopped in Ahlat. ${ }^{31}$ Although there is no record on the nature of his stay, it is possible that he may have intended to consolidate Ilkhanid authority in the city after T'amt'a's death. The limited Mongol contingent that was left behind in Syria was ultimately defeated in the Mamlük counterattack at 'Ayn Jālūt in 1260 and Hülegü 's subsequent military engagements were directed against the Mongol Jochid dynasty of the Golden Horde. The Jochids had been the main director of Mongol western expansion and the immediate Chinggisid authority to which Baiju had answered. Following his invasion of Syria, Hülegü 's relations with the Jochids deteriorated, leading to the execution of Baiju and war with the Golden Horde starting in the winter of 1261-1262. ${ }^{32}$ Ahlat's political alignment following these events must have remained squarely within the Ilkhanid ambit, eventually being recognized, according to the Persian geographerhistorian Hamdallāh Mustawfi writing around 1340, as the capital of the province of Greater Armenia with the administrative status of a tumann that was expected to mobilize 10,000 soldiers for the Ilkhanid army. ${ }^{33}$ Whether the city enjoyed this official status already in the 1270 s and early 1280 s when locally based Ilkhanid amirs under the aegis of Hülegü's son and successor Abaqa Ilkhan (r. 1265-1282) invested in funerary monuments to their name cannot be known for certain, but their investments reflect the significance of Ahlat towards the end of the thirteenth century.

\footnotetext{
26 Jackson, Mongols and the Islamic World, 84.

27 On the remarkable life story of T'amt'a, see Eastmond, Tamta's World; Pogossian, Women.

28 Sublet, Princesse Bint al-Ašraf, 47; Demir, Ahlât Eyyûbîleri, 230-231. The Muslim sources diverge from the Armenian sources with regard to T'amt'a's whereabouts between 1230 and 1245, placing her in Damascus rather than on the whirlwind tour of Eurasia. Nevertheless, Muslim and Armenian sources agree on her return to Ahlat in 1245 by official Mongol decree.

29 Pogossian, Women, 235.

30 Pogossian, Women, 234.

31 Jackson, Mongols and the Islamic World, 130-133; Amitai-Preiss, Mongols and Mamluks, 26-28.

32 Jackson, Bāyjū.

33 Hamdallāh Mustawfi, Nuzhat-al-Qulūb, 100.
} 


\section{Tracing the Remains of Medieval Ahlat}

Studying the urban fabric of medieval Ahlat is handicapped by the general absence of any standing public or institutional buildings surviving from the pre-Ottoman period, with the exception of the small and plain masjid built by the Aqqoyunlu amir Bayındır in 1477 next to his tomb tower dated 1481. Although two major military assaults - the Khwārazmshāh siege of 1229-30 and a Safavid siege in 1552 - must have played some role in bringing about this situation, further destruction of the city's non-defensive buildings must have occurred in the three major earthquakes of the thirteenth century that appear to have had their epicenters in or near Ahlat. ${ }^{34}$ The earliest of these occurred in 1208 and was associated with landslides. Another earthquake rattled the city in 1246 and evidently caused significant damage. But it was the earthquake of 1275-76 that seems to have caused massive destruction and was recorded in a number of thirteenth- and fourteenth-century sources as a force which leveled buildings from Ahlat to Erciş. That a comprehensive reconstruction of the medieval urban center was never realized is conveyed by the seventeenth-century Ottoman traveler Evliya Çelebi's description of it as a haräbistān (»land of ruins") where abandonment and neglect turned the glorious buildings of the past into "pigeon, crow and owl nests" (kebûter u zâğ $u$ bûm âşiyânları olmuş). ${ }^{35}$

There are also no remains within Ahlat itself of any Armenian architecture, either pre- or post-seventh century, nor are any recorded in travelers' reports prior to the twentieth century. The closest Armenian monastic site, known as Madavans (Matnavank in Armenian), is located about five kilometers to the north of Ahlat and consists of a rock-carved church with an attached zhamatun that was destroyed sometime in the twentieth century (Fig. 2). ${ }^{36}$ The monastery was mentioned in a colophon dated 1348 and the remains of the former zhamatun were tentatively dated to the early fourteenth century. However, to judge by the presence of a number of associated rock-carved dwellings/chapels and an Armenian cemetery, the history of the site may well go back to an earlier medieval period. A number of other Armenian rockcarved monastic settlements have been identified in the hinterlands of Ahlat. ${ }^{37}$ Thus, Armenian religious architecture, which must have certainly also been within Ahlat in the pre- and early Islamic periods, apparently receded to the surrounding suburban and rural areas in the course of the medieval period. ${ }^{38}$

36 Thierry, Vaspurakan, 213-218. For a description of the site in the mid- and late nineteenth century, see Layard, Discoveries, 30-31; Lynch, Armenia, 293.

37 For a map showing these sites, see Bixio and De Pascale, Underground settlements, 128. About 16 kilometers to the northwest of Ahlat, in the village of Ovakışla (formerly Prkhus), is a church dedicated to St. Stephen which is datable to the seventeenth century but which incorporates decorative material that evidently goes back to the early medieval period; Thierry, Vaspurakan, 219-223.

38 Al-Nuwayrī, a Mamlūk historian of the early fourteenth century, mentioned that a church was built in Ahlat for T'amt'a by her first husband, al-Awhad; La Porta, Legitimizing land and power, 88, n. 79. No trace of a church has been documented in Ahlat, but such a church, if it existed, would most likely have been within the citadel on which no systematic survey has been undertaken. 


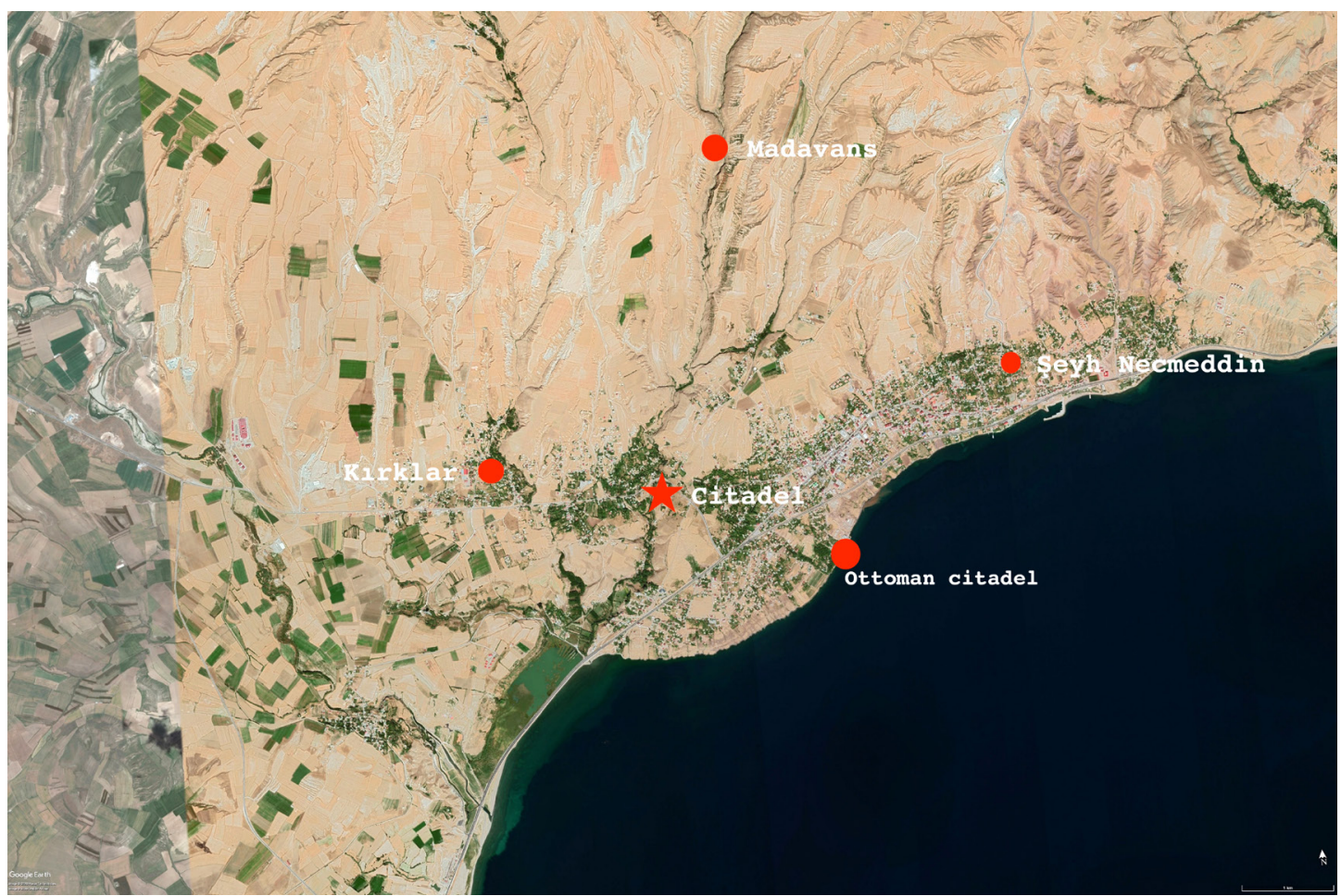

Fig. 2: Satellite view of Ahlat and environs (Source: Google Earth view, 30 September 2019)

The Armenian historian Vardan Arawelts'i, who praised the Shāh-i Arman Sukmān II for his benevolence to Christians, recounted the story of an Armenian priest named Awet who became a wandering preacher caring for the dispossessed and crossed paths with Sukmān II who paid him great honors. ${ }^{39}$ Subsequently falling victim to the slanders of priests, Awet was stoned to death, but the miraculous appearance of a divine light over his dead body evidently persuaded Sukmān II to arrange for the veneration of the saintly preacher's bones. An anonymous and unepigraphic tomb tower in Ahlat, locally known as Keşiş Kümbeti (»Tomb of the Monk«) and datable stylistically to the late fourteenth or fifteenth centuries, may possibly be a later reconstruction of a Shāh-i Arman funerary monument to this Christian holy man. ${ }^{40}$

Ahlat's medieval citadel, of which only some traces remain today, extends in a northsouth direction on a ridge delineated by a ravine on either side, somewhat similar to, though less dramatic than, the much better preserved citadel of Bitlis (Fig. 3).

39 Thomson, Historical Compilation, 204-205.

40 Tabak, Ahlat, 27-28; Uluçam, Bitlis, 229-230. 


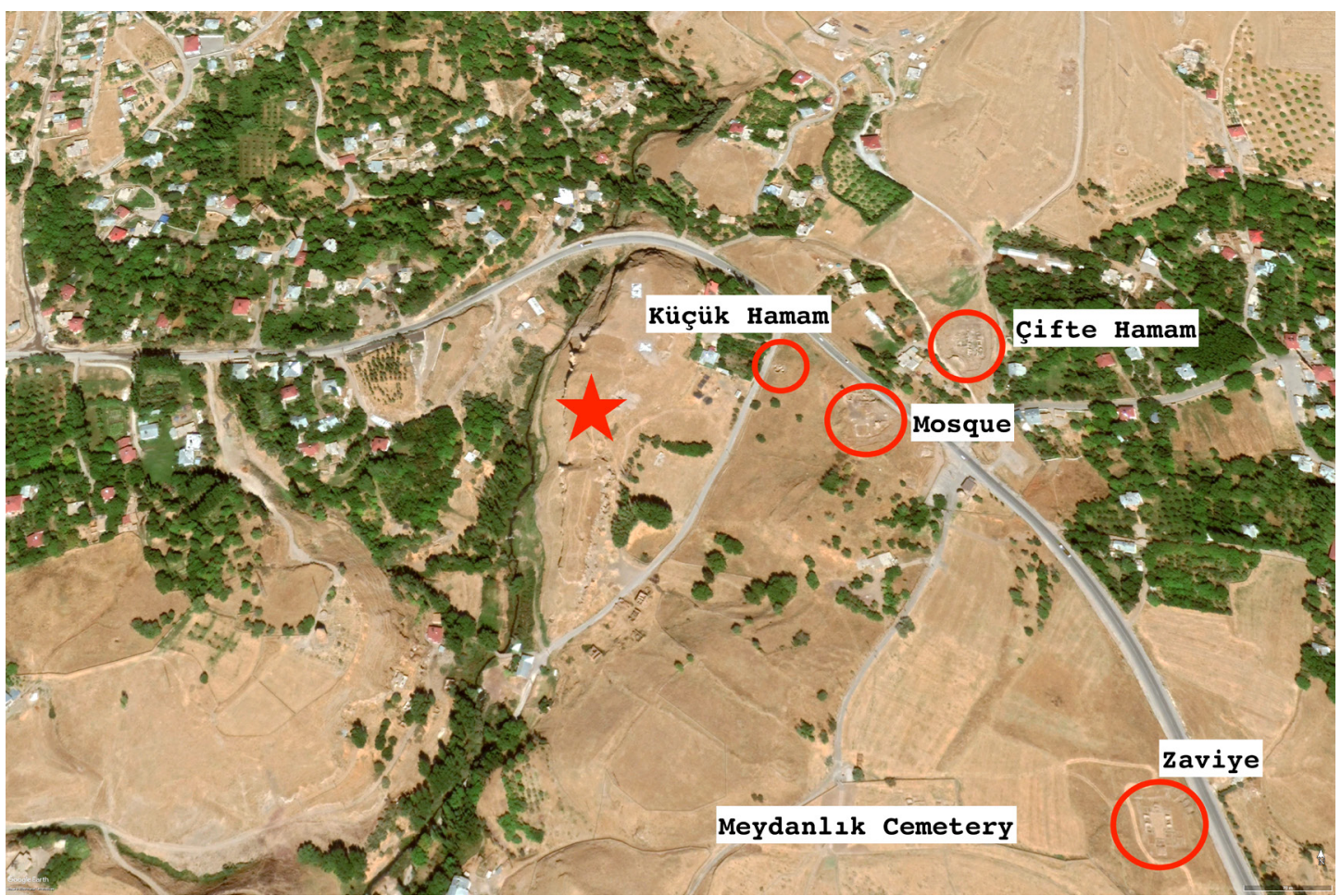

Fig. 3: Satellite view marked with Ahlat's medieval citadel and Harabeşehir (Source: Google Earth view, 30 September 2019)

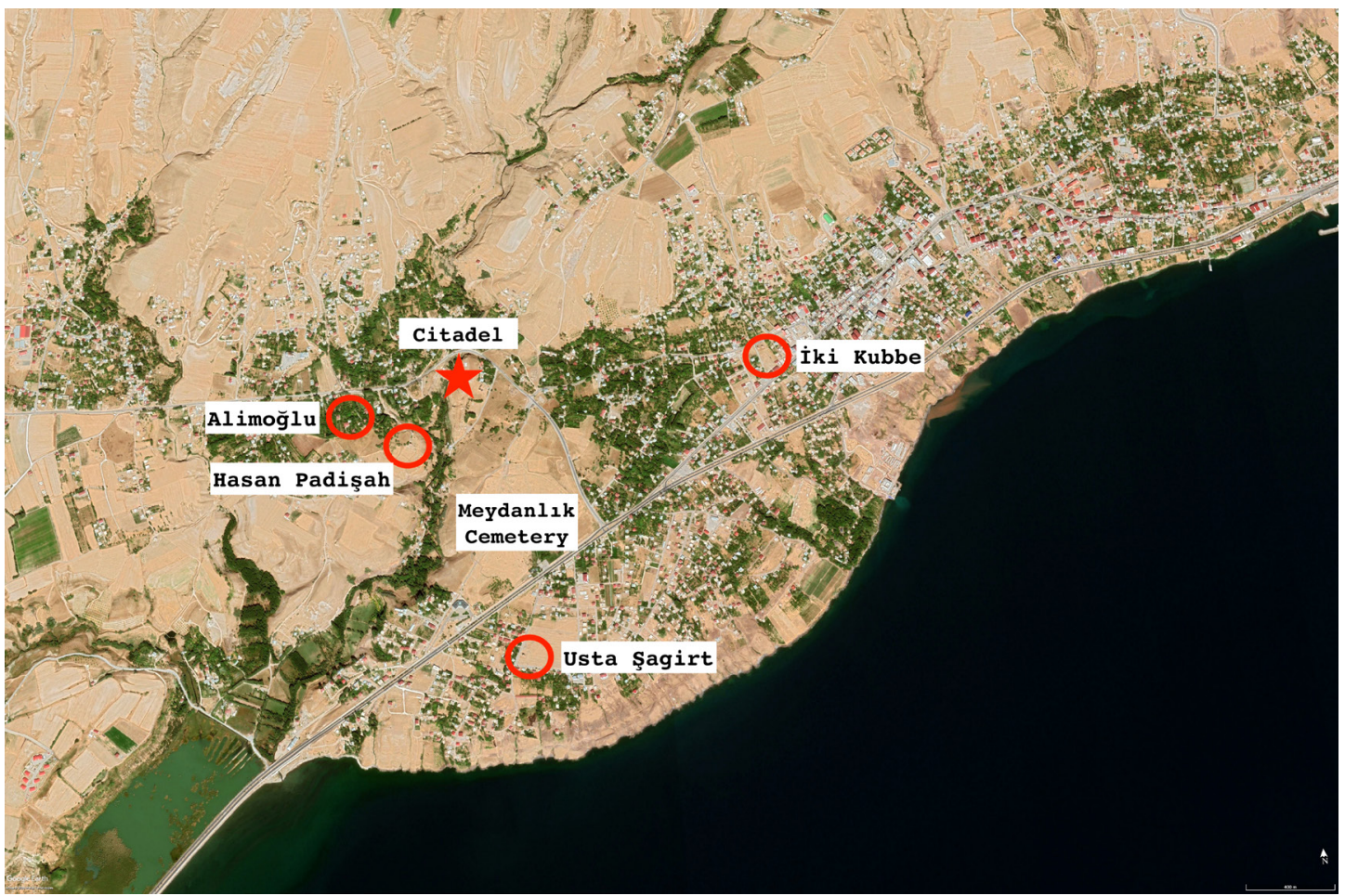

Fig. 4: Satellite view marked with locations of the Ilkhanid tomb towers (Source: Google Earth view, 30 September 2019) 
A stream known as Keş Deresi flows from the north through the narrow and deep western ravine of the citadel while the gentler slopes of the eastern ravine are locally known as Harabe Şehir (»Ruined City," corresponding to Evliya Çelebi’s harâbistân) with their distinctive rock-carved cave dwellings below the eastern citadel walls. ${ }^{41}$ Although the scant remains of its walls and towers remain undated, it seems reasonable to assume that at least the foundations of the citadel are the oldest structures to be associated with medieval Ahlat, probably predating the Arab-Muslim conquests. The citadel evidently constituted the northwestern quadrant of Ahlat's city walls, of which very meager remains have been identified. ${ }^{42}$ Although much battered in the Khwārazmshāh assault of 1229-1230, the citadel must have been repaired and continued to function until the sixteenth century. ${ }^{43}$ It was in the context of the Ottoman-Safavid wars that the citadel received the final blow: the successful Safavid siege in the summer of 1552 was followed by Shāh Ṭahmāsp's order to have the citadel razed. ${ }^{44}$ When the Ottomans regained control of the region a few years later, the old citadel was abandoned in favor of a new citadel constructed beyond the city walls, by the lakeshore (Fig. 2). ${ }^{45}$

To the east and northeast of the eastern ravine of the medieval citadel, a number of excavated buildings of uncertain dating round out the current state of knowledge on Ahlat's medieval urban fabric. ${ }^{46}$ Of these excavated buildings, two are indubitably identified as bathhouses. One of them, of an unconventionally small size and thus labeled as Küçük Hamam ("Small Bathhouse"), is located across from the citadel on the eastern slope of the eastern ravine, at its northern end. A much larger double bathhouse (known as Çifte Hamam) is located further to the northeast and is situated immediately on the exterior side of a bastion tower that probably belonged to the northern extension of the city walls. ${ }^{47}$ Approximately

41 For a plan of the rock-carved dwellings below the citadel, see Bixio et al., Ahlat 2010, 23.

42 For descriptions of the citadel and the remains of the city walls (mostly in the form of foundations of bastion towers), see Lynch, Armenia, 291-292; Beygu, Ahlat Kitabeleri, 66-67; Kafesoğlu, Ahlat ve Çevresinde, 171-172; Karamağaralı, Ahlat Kazıları, 84-85. The most systematic surveys of the medieval city published so far have been undertaken in conjunction with a project on the rock-carved sites in and around Ahlat carried out by Roberto Bixio and Andrea De Pascale. For a partial map of the city showing identified remains of the city walls (marked on the map as »burç» or »burçlar«), see Bixio et al., Ahlat 2010, 6. More rudimentary maps were published earlier: Lynch, Armenia, foldout between 296 and 297; Bachmann, Kirchen und Moscheen, 58; Gabriel, Şarki Türkiye'de Arkeolojik Geziler, 210; Kafesoğlu, Ahlat ve Çevresinde, foldout between 190 and 191.

43 Ibn Bỉbì specifically mentions that repairs to the citadel were undertaken during the brief Rum Seljuq occupation, Ibn Bībī, El-Evāmirü'l-'Alä’iyye [facsimile edition], 427, trans. Öztürk, 427.

44 Musalı, Safevî-Osmanlı Savaşları, 23-25.

45 For the Ottoman citadel, see Tabak, Ahlat, 44-45; Top, Osmanlı Kalesi.

46 For a basic overview, see Karamağaralı, Ahlat Kazıları. More recently, see Arslan, Ahlat Şehri; Arslan, Ahlat Kazılarının Dünü-Bugünü.

47 Aksulu et al., Restitution. 
130 meters to the southwest of this bathhouse is another excavated site where the meager remains of what has been interpreted as an octagonal minaret base attached to a wall with a mihrab has been putatively identified as the city's congregational mosque (Ulu Cami), although questions surround this identification..$^{48}$ Neither the bathhouses nor the mosque elements have been dated conclusively, with suggestions ranging from the early Islamic period to the Ilkhanid and Aqqoyunlu periods.

Due south of these buildings (and to the east of the eastern ravine of the citadel) is the largest medieval cemetery of Ahlat, known as the Meydanlık (or Meydan) cemetery, covering an area over two square kilometers. ${ }^{49}$ Containing thousands of tombstones that are dated or datable between the early twelfth and the early sixteenth centuries and displaying a remarkable repertoire of fine stone carving applied to a variety of tomb types, this cemetery stands as a testament to the continuity of artistic resources at the disposition of Ahlat's medieval and early modern inhabitants..$^{50}$ In addition to the tombstones, the cemetery also contains numerous underground burial chambers (locally known as akit), a phenomenon encountered elsewhere in Ahlat. ${ }^{51}$ This cemetery, along with the other five medieval to early modern cemeteries of Ahlat, ${ }^{52}$ constitutes a great reserve of prosopographic data awaiting comprehensive documentation and analysis. The earliest tombs, which are characterized by prismatic cenotaphs bearing Kufic inscriptions and no head or footstones, date from the turn of the twelfth century to the $1160 s,{ }^{53}$ corresponding to the ascendance of the Shäh-i Arman dynasty and lending further support to the revitalization of Ahlat especially during the reign of Sukmān II. These early tombs are concentrated in the northeastern section of this vast cemetery and indicate that the expansion of the burial ground generally occurred from the north to the south. Tombs with headstones and footstones in the form of tall stelae at either end of cylindrical or rectilinear cenotaphs appeared in the last quarter of the twelfth century and became the characteristic tomb type not only in Ahlat but also across the region.

Initial analysis of the Meydanllk cemetery tombs with stelae indicates phases of production between the late twelfth and the early sixteenth centuries with significant lacunae that correspond to periods of disastrous events, most notably in the second quarter of the thirteenth century $^{54}$ as a result of the upheaval caused by the Khwārazmshāh assault of 1229-1230 followed by the earthquake of 1246. Production picked up in the latter part of the thirteenth century, reaching a highpoint in the early fourteenth century in terms of quality and quantity but

48 Haluk Karamağaral, who undertook the excavation of this and other sites in Ahlat between 1967 and 1991, suggested that this so-called Ulu Cami was built in the Ilkhānid period and that Ahlat's "first" Friday mosque must have been located in the Tahtı Süleyman neighborhood located on the other side of the citadel's western ravine; Karamağaral, Ahlat Kazıları, 91. For the latter claim, Karamağaralı referred to the remains of a brick minaret said to be in the Tahtı Süleyman neighborhood, without giving further details. No other study on Ahlat mentions such a structure.

49 Karamağaralı, Ahlat Mezartaşlarl; Karahan et al., Meydan Mezarlı̆̆ı. For a recent plan of the cemetery, see Avşar and Güleç, Analiz Çalışmaları, 4. For excavation reports, see Karahan and Güzel, Eski Ahlat Şehri Kazıları (20112012) and Karahan et al., Eski Ahlat Şehri Kazıları (2013).

50 In the most recent publication of the current excavation team (Karahan et al., Meydan Mezarlı̆ğ, 37), the total number tombs identified in the Meydanllk cemetery is given as 4362. Of these, around a thousand have distinctive stele-type tombstones.

51 On akıts, see Karamağaralı, Tümülüs; Karamağaralı, Ahlat Kazıları, 85-90; Karahan et al., Meydan Mezarlı̆̆l, 80-85.

52 Karamağaral, Ahlat Mezartaşları, 34-35; Karahan et al., Meydan Mezarlğ̆l, 36-37.

53 Karamağaral, Ahlat Mezartaşları, 36-44.

54 Karamağaral, Ahlat Mezartaşları, 44. 
leveling off towards the middle of the century (corresponding to the collapse of the Ilkhanate) and petering out thereafter until the beginning of the fifteenth century ${ }^{55}$ These observations tally closely with the broader social, cultural and political patterns characterizing the course of the Pax Mongolica in the late thirteenth and fourteenth centuries and suggest that Ahlat's fortunes waxed and waned in tandem with late medieval Turco-Mongol hegemony in west Asia. Thus, the Meydanllk cemetery can be read as a mirror of urban vitality in Ahlat with the lacunae in the funerary record corresponding to periods of destruction and decline in urban life. The preservation of the Meydanllk cemetery as a space largely immune to urban obliteration is also suggested by the excavation of two underground chambers evidently repurposed into a temporary residence, possibly in the aftermath of the earthquake of $1276 .{ }^{56}$

Further evidence for the transformation of a funerary site into a living space comes from the foundations of a building identified as a zäwiya (Sufi lodge) to the northeast of the Meydanllk cemetery. Excavations carried out at this site have brought to light the crypt of an earlier tomb tower that appears to have been incorporated to the southern side of a rectangular building with two ìwāns and rooms arranged around a courtyard. Although the dating is not certain, it has been suggested that the tomb tower may have been constructed in the twelfth century ${ }^{57}$ while the rectangular zäwiya was built to develop the site, possibly in the early fourteenth century. ${ }^{58}$ The reasons for identifying the building as a $z \bar{a} w i y a$ have not been explained by the excavators, but the incorporation of the earlier tomb tower can be interpreted as an act of symbolic appropriation which can be reasonably contextualized in a Sufi context. In the mid-sixteenth century, two tax registers (tahrir defteri) - one detailed (mufassal), the other summary (icmāl) - were compiled in the context of the Ottoman takeover of the Lake Van region..$^{59}$ The detailed tax register lists some nine zäwiyas in and around the sub-district (nahiye) of Ahlat; more are listed in the summary register. Two of the zâwiyas can be dated to the fifteenth century: one was built by the Aqqoyunlu amir Bayındır in the 1470s together with a mosque (masjid) and tomb tower which are still extant just north of the Meydanlık cemetery; another, named after a certain Şeyh Ammar-i Ahlati, can be dated to the early fifteenth century on the basis of its surviving endowment deed dated $1420 .{ }^{60}$ Others, however, were founded earlier, as in the case of the zäwiya of Şeyh Necmeddin, of which the tomb building dated 1220 still stands in the eastern Ergezen neighborhood of Ahlat (Figs. 2, 5) ${ }^{61}$

55 Karamağaral, Ahlat Mezartaşları, 45.

56 Karamağarall, Ahlat Kazıları, 89-90.

57 Arslan, Ahlat Kent Dokusu, 14.

58 Karamağaralı, Ahlat Kazıları, 93-94 where the early fourteenth-century suggestion is based on ceramic findings.

59 The detailed tax register (Tapu Tahrir Defteri, no. 413) pertains to the region of Bitlis, whereas the summary tax register (Tapu Tahrir Defteri, no. 297) concerns the area of Adilcevaz, including Ahlat; Tekin, Türk Tarihinde Ahlat, 200-202. Although Tekin gives the date of 1555-56 (AH 963) for both registers, the detailed register is apparently undated and may be earlier than the summary register; for a 1540 dating, see Altunay, Bitlis Sancağl, 6-7. On the detailed register, see also Yllmaz, Bitlis Sancağ (where the 1555-1556 dating is maintained without explanation). For the summary register, see Çal, Tapu Tahrir Defterleri; Kilıç, Adilcevaz ve Ahlat. Only Tekin (Türk Tarihinde Ahlat) utilizes both registers.

60 Tekin, Türk Tarihinde Ahlat, 214-217, 219-222.

61 Beygu, Ahlat Kitabeleri, 87-89; Tabak, Ahlat, 11; Tuncer, Anadolu Kümbetleri, 68-70; Uluçam, Bitlis, 241-243; Önkal, Anadolu Selçuklu Türbeleri, 214-217. In the fourteenth century, a tomb tower for Erzen Hatun was built several meters to the east of the Şeyh Necmeddin tomb. 


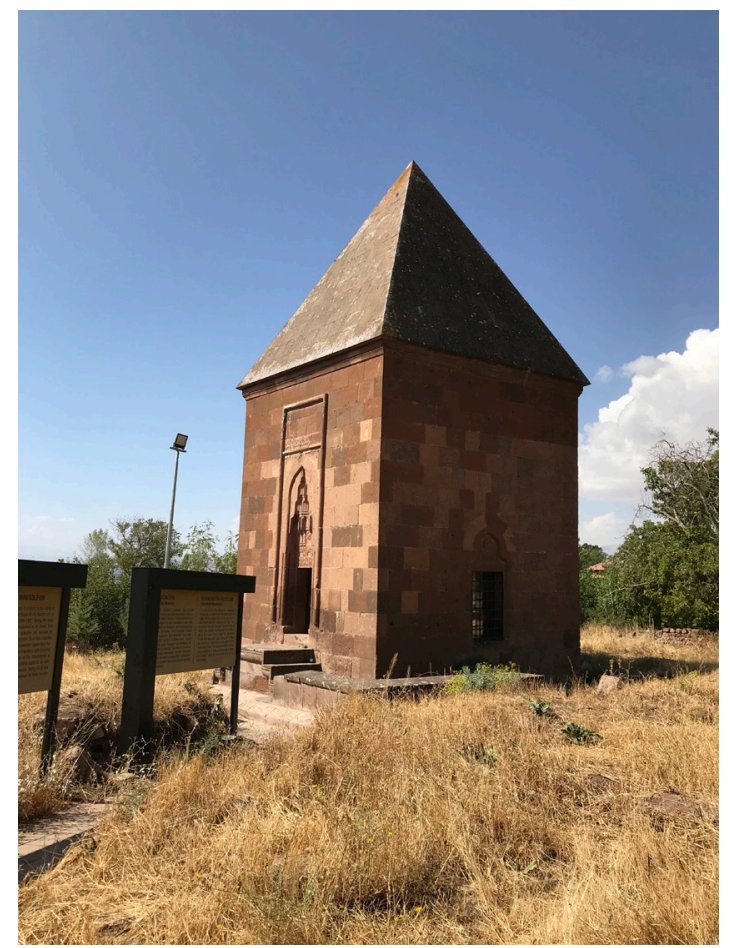

Fig. 5: Tomb of Şeyh Necmeddin (photo by the author, September 2018)

At least four other zäwiyas were similarly located in the outskirts of Ahlat and conceivably may have been founded around the same time as that of Şeyh Necmeddin. These include the zâwiya of Şeyh Abdülkadir in a village called Pağdos, the zāwiya of Kırklar in an eponymous settlement (with a medieval cemetery containing some thirteenth-century tombstones) to the northwest of the medieval citadel (Fig. 2), the zäwiya of Baba Merdan to the north of the city on the road to Malazgirt and the zāwiya of Şeyh Yoldaş, recorded as being »near Ahlat. « ${ }^{62}$

In contrast to the apparent profusion of zäwiyas, the detailed tax register for Ahlat lists only a single madrasa, named Zeamiye, recorded as ruined and out of use, and only one Friday mosque, the so-called Cami'-i Ahlat. ${ }^{63}$ Although it is not possible to know the foundation dates of either of these two institutions, it seems that both were seriously compromised prior to the Ottoman takeover as suggested by the fact that only a single source of endowed income

62 Tekin, Türk Tarihinde Ahlat, 219, 222-225. The village named Pağdos is probably the same as the Patnos (later renamed Soğanll) recorded in the early twentieth century as a village in the administrative district of Ahlat; see Dahiliye Vekaleti, Köylerimiz, 414. Soğanlı is located about 10 kilometers east of Ahlat. Pağdos/Patnos should not be confused with the larger settlement of Patnos north of the Lake Van region. On the Kurklar cemetery, see Karamağaralı, Ahlat Mezartaşları, 34.

63 Tekin, Türk Tarihinde Ahlat, 213, 226-227. Subsequent to the compilation of the two tax registers, two mosques (İskender Paşa Cami and Kadı Mahmud Cami) were built inside the new Ottoman citadel. That there was a Friday mosque in Ahlat in the Abbasid period can be deduced from the mention of a mosque desecrated in the context of a Byzantine incursion in 928; see Sümer, Doğu Anadolu'da Türk Beylikleri, 49. 
was recorded for each. The meager endowment of the mosque - constituting one-eighth of the grain of a village nearby - stands in stark contrast to the Ulu Cami (Friday Mosque) of nearby Adilcevaz which was recorded as being generously endowed with income from numerous orchards, estates, houses and shops. ${ }^{64}$ The light fiscal footprint of both mosque and madrasa in Ahlat and the clear indication of the latter's loss of function due to its ruinous state suggest a case of neglect or a deliberate reduction of endowed resources over time rather than a single discrete blow. Whatever may have been the case, it is remarkable that only one Friday mosque and one madrasa are recorded, amounting to a dearth of normative institutions that stands in stark contrast to the numerous and well-endowed zäwiyas in and around the city. ${ }^{65}$ This situation probably took hold gradually in the period between the Khwārazmshāh assault of 1229-1230 and the Ottoman takeover in the mid-sixteenth century. Just before the Khwārazmshāh assault, Husām al-Dīn 'Alī, the Ayyubid governor of the city, is reported to have built a Friday mosque and a hospital. ${ }^{66}$ These two institutions probably did not escape the Khwārazmshāh attack unscathed, so that mentions of Cami'-i Ahlat and the Zeamiye madrasa in the tax registers may possibly be sixteenth-century traces of the Ayyubid foundations. ${ }^{67}$

On the basis of these records and observations about the urban institutions of preOttoman Ahlat, the following scenario can be proposed. In the period between the pinnacle of Shāh-i Arman rule in the mid- to late twelfth century and the Khwārazmshāh attack on the Ayyubid city in 1229-1230, Ahlat must have enjoyed a vibrant urban life but the physical remains of this period have not been - and possibly cannot be - documented, except in the impressive development of the tombstones in the Meydanllk cemetery. ${ }^{68}$ The tail end of this period appears to have witnessed the foundation of zäwiyas with a funerary component and a Sufi identity, such as that of Şeyh Necmeddin and Kırklar, in the area surrounding the city.

64 For the income of the Ahlat mosque, see Altunay, Bitlis Sancağl, 497; Yllmaz, Bitlis Sancağl, 97; Tekin (Türk Tarihinde Ahlat, 213) gives the share as one-fourth. For the income of the Adilcevaz mosque, see Kılıç, Adilcevaz ve Ahlat, 88-96.

65 It is also worth mentioning that the sixteenth-century tax registers do not record any masjids (neighborhood mosques) for Ahlat. In Bitlis, by contrast, some 23 masjids were recorded in the sixteenth century, in addition to the main Friday mosque (Ulu Cami); see Koçak, Bitlis Camileri ve Mescitleri.

66 Ibn al-Athïr, Chronicle, trans. Richards, 295-296.

67 In this conjecture, the discrepancy between Husām al-Dīn 'Alī's hospital and the sixteenth-century reference to a madrasa may be explained with reference to other cases of hospitals in Anatolia that were later transformed into madrasas. Such was the case for the Mengujekid hospital in Divriği that, by the fourteenth century, was functioning as a madrasa. It is interesting to note that the hospital in Divriği was also built together with a Friday mosque, around the same time as Husām al-Dīn 'Alī's patronage in Ahlat and was signed by craftsmen from Ahlat; Pancaroğlu, Mosque-hospital complex.

68 The Ahlat Museum has on display in its garden a good number of sizable stone blocks with inscriptions and/or carved decoration. Some of them can be stylistically identified as belonging to twelfth- and thirteenth-century buildings which were conceivably damaged and destroyed either in the Khwārazmshāh attack, or, more likely, in the two earthquakes of 1246 and 1276. It stands to reason that the collapse of medieval buildings constituted a reserve of reusable building materials both for the construction of ordinary houses in and around Ahlat in subsequent centuries and especially for the construction of the Ottoman lakeshore citadel in the sixteenth century. Indeed, reused twelfth- or thirteenth-century building blocks with decoration can be easily observed on the walls around the gate of the Ottoman inner citadel. 
The post-Khwārazmshāh period from the 1230 s to the 1250 s witnessed a brief period of Rum Seljuq intervention in the beginning, but no physical sign of this has been identified. The lacuna in the tombstone record and the absence of any structures that can be dated to this period suggest some degree of urban stalemate. In the second half of the thirteenth century, vibrancy appears to return to Ahlat under the aegis of the Ilkhanid amirs, as evinced both by the tombstones in the Meydanllk cemetery and the numerous and distinctive tomb towers built in the area surrounding the city center for Muslim Ilkhanid amirs. However, unlike the case of Şeyh Necmeddin whose tomb building and associated zäwiya in the Ergezen neighborhood was secured by an endowment that survived into the Ottoman period, it is notable that none of these late thirteenth-century tomb towers appear to have been connected to an endowed foundation such as a zawwiya or a madrasa. While it is possible that their endowments were somehow destroyed, abrogated or expropriated in the post-Ilkhanid period, the total silence of the Ottoman tax registers regarding these tomb towers and the figures associated with them and the absence of any physical remains other than the tombs suggest that a particular situation applies to this group of buildings which will be examined in the following sections.

Ahlat's urban vitality evidently continued into the fourteenth century, as attested by the truly impressive series of tombstones in the Meydanlık cemetery as well as the smaller Tahtı Süleyman cemetery to the west of the medieval citadel, but no large-scale construction can be associated with this otherwise bright period. A new period of stalemate seems to take hold gradually through the course of the fourteenth century in the context of the post-Ilkhanid fragmentation of power in both Iran and Anatolia. With the reconsolidation of power under the Aqqoyunlu at the beginning of the fifteenth century, a renewal in zāwiya activity becomes evident, this time focused on the urban center, in the form of the zäwiyas of Şeyh Ammar al-Ahlati and amir Bayındır.

\section{Tomb Towers of the Ilkhanid Amirs, 1270 s-1280s}

Perched on the hill to the west of the citadel is the earliest dated tomb tower of the Ilkhanid period in Ahlat (Figs. 4, 6-7) ${ }^{69}$ This dramatically sited monument is locally known as the tomb of Hasan Padişah (Ḥasan Pādishāh) and is largely characteristic of a series of tomb towers built in the 1270 s and 1280 s. $^{70}$ Consisting of a lower chamber or crypt with a square plan that is partially below ground level and an upper chamber in the form of a cylindrical body surmounted by a conical dome, it has the same lofty and soaring presence as the others but this impression is compounded here by the hilltop location. The chamfered corners of

69 Beygu, Ahlat Kitabeleri, 67-68; Gabriel, Şarki Türkiye'de Arkeolojì Geziler, 213-214, 274; Tabak, Ahlat, 15-16; Tuncer, Anadolu Kümbetleri, 76-83; Uluçam, Bitlis, 211-215; Önkal, Anadolu Selçuklu Türbeleri, 183-186.

70 The Hasan Padişah tomb was in a ruinous state with only about a quarter of the structure standing since at least the end of the nineteenth century (as described by Lynch, Armenia, 292). It was restored with mostly original blocks found at the site in 1969 (see Tuncer, Anadolu Kümbetleri, 78-79). 
the lower square chamber produce a short twelve-sided zone of transition upon which the shaft of the round upper chamber rises. Like all of the other examples in this group, this tomb tower features four openings around the cylindrical upper chamber, of which three are in the form of windows and the fourth in the form of a doorway. These openings mark the cardinal points around the cylindrical body with the doorway on the north and three windows on the east, south and west sides. The lower chamber has a subterranean entrance on the eastern side and features three small windows on the east, west and south sides (and none on the north side).$^{71}$

The Hasan Padişah tomb is constructed of fine ashlar masonry facing a rubble core both on the interior and the exterior. The exterior decoration articulates the surface of the cylindrical body in the form of ornamental moldings forming eight large panels, each surmounted by a double arch. These panels surround the four openings and, alternating with them, four elongated niches. A muqarnas niche crowns each of the four openings and muqarnas is also featured as a frieze just below the cornice of the dome. A two-line inscription above the muqarnas niche of the doorway identifies this tomb tower as a rawda (literally, "garden") and gives the name of one Hiasan Āqà b. Mahmūd, with the titles of al-mawlā (»master«) and malik al-umarä' (»king of emirs«), and the date of Rajab 673 (January 1275). ${ }^{72}$ Although this name has not been encountered in the historical sources, the grand title and the commanding location of the tomb tower suggest that Ḥasan Āqa claimed preeminence in Ahlat in the early period of Ilkhanid domination in the region.

71 The Hasan Padişah tomb and the others in the same group were all outfitted with double-sided stairs in the course of restoration work undertaken in the 1960s and 1970s. Orhan Cezmi Tuncer, the architect and architectural historian who was in charge of the Hasan Padişah restoration in 1969, justified this addition by claiming that the foundation of a stairway - separate from the foundation of the tomb tower but adjacent to it on the north side was found in the course of restoration works (Tuncer, Anadolu Kümbetleri, 81). He published two photographs (p. 78) of stone blocks which he identified as steps belonging to the original stairs. However, the poor quality of the photographs and the lack of an explanatory drawing make it difficult to be persuaded. Tuncer also pointed out that none of the lower chambers of tomb towers in this group have a window on the north side, a peculiar feature which he offered as further evidence for a stairway (p. 80). It is curious, nonetheless, that no original stairway (nor a partial one) was preserved at any of the tomb towers. The idea of an original stairway was rejected by Ünal (Doğu Anadolu Künbetleri, 126, n. 3). Ünal suggested instead that the upper chambers must have been accessed by portable ladders, an idea that was earlier put forth by Albert Gabriel (Şarki Türkiye'de Arkeolojïk Geziler, 211, n. 13). All of these scholars operated on the assumption that the upper chambers were meant to be accessed.

72 The few words at the end of the first line of the inscription (following the title malik al-umarä') have not been satisfactorily deciphered. The second line begins with the name Ḥasan Āqā b. Mahmūd. 


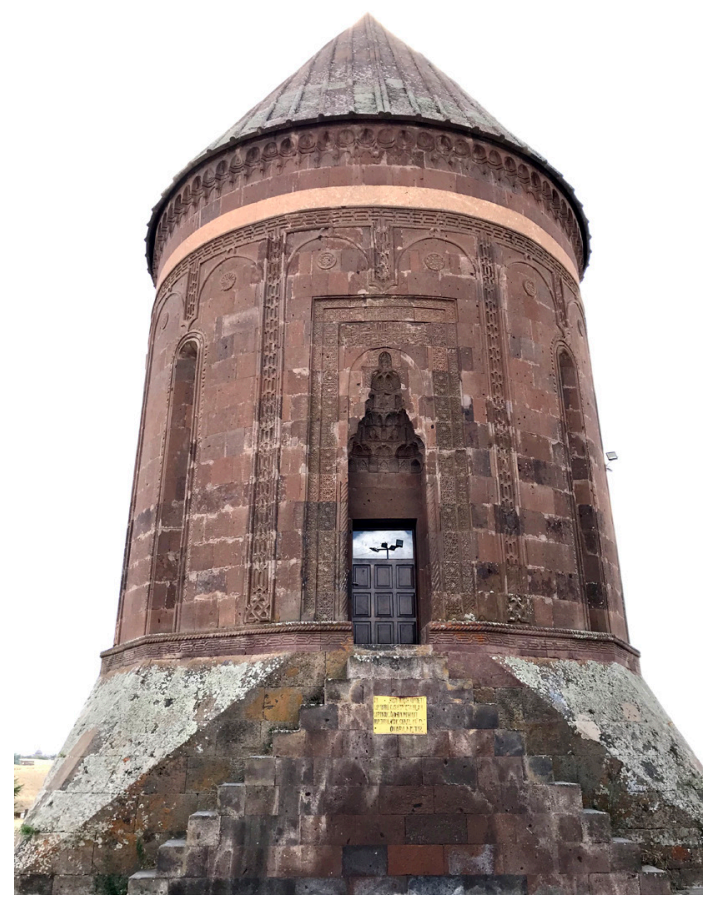

Fig. 6: Hasan Padişah tomb tower, view from the north (photo by the author, September 2018)

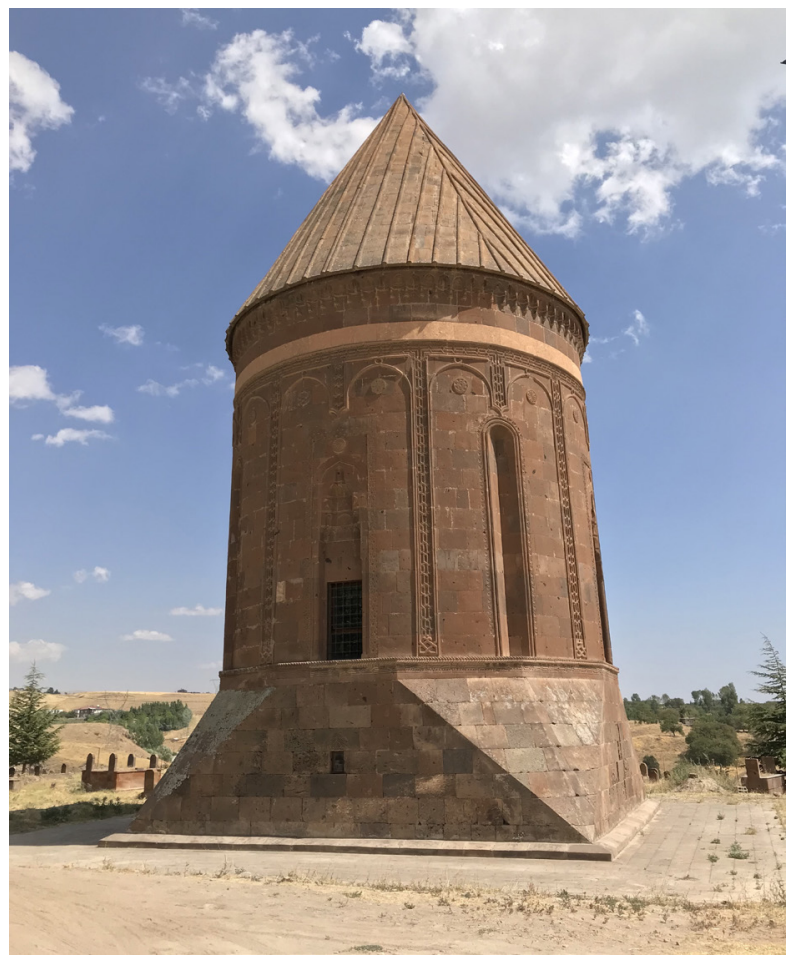

Fig. 7: Hasan Padişah tomb tower, view from the south (photo by the author, September 2018) 
Some twenty meters to the north of the Hasan Padişah tomb is the lower part of another tomb tower which evidently collapsed at some point (Fig. 8). ${ }^{73}$ The architecture of the extant base is similar enough (albeit smaller in size) to that of Hasan Padişah that it seems reasonable to assume that they were built approximately around the same time. Judging by the decoration of its lower chamber windows, which are the most decorative of all the examples in Ahlat, this tomb tower must have been at least as fine as its companion, the Hasan Padişah tomb. Without any inscriptional identifier, however, it is not possible to establish its relationship to Ḥasan Āqā b. Mahmund but, as is the case with the other pairs of tombs in Ahlat, it is probable that some familial relationship informed the construction of these two tombs next to each other. Located on a high and dominant site with broad views onto the citadel, Harabe Şehir and beyond, these two tombs would have been the most easily visible markers on Ahlat's landscape.

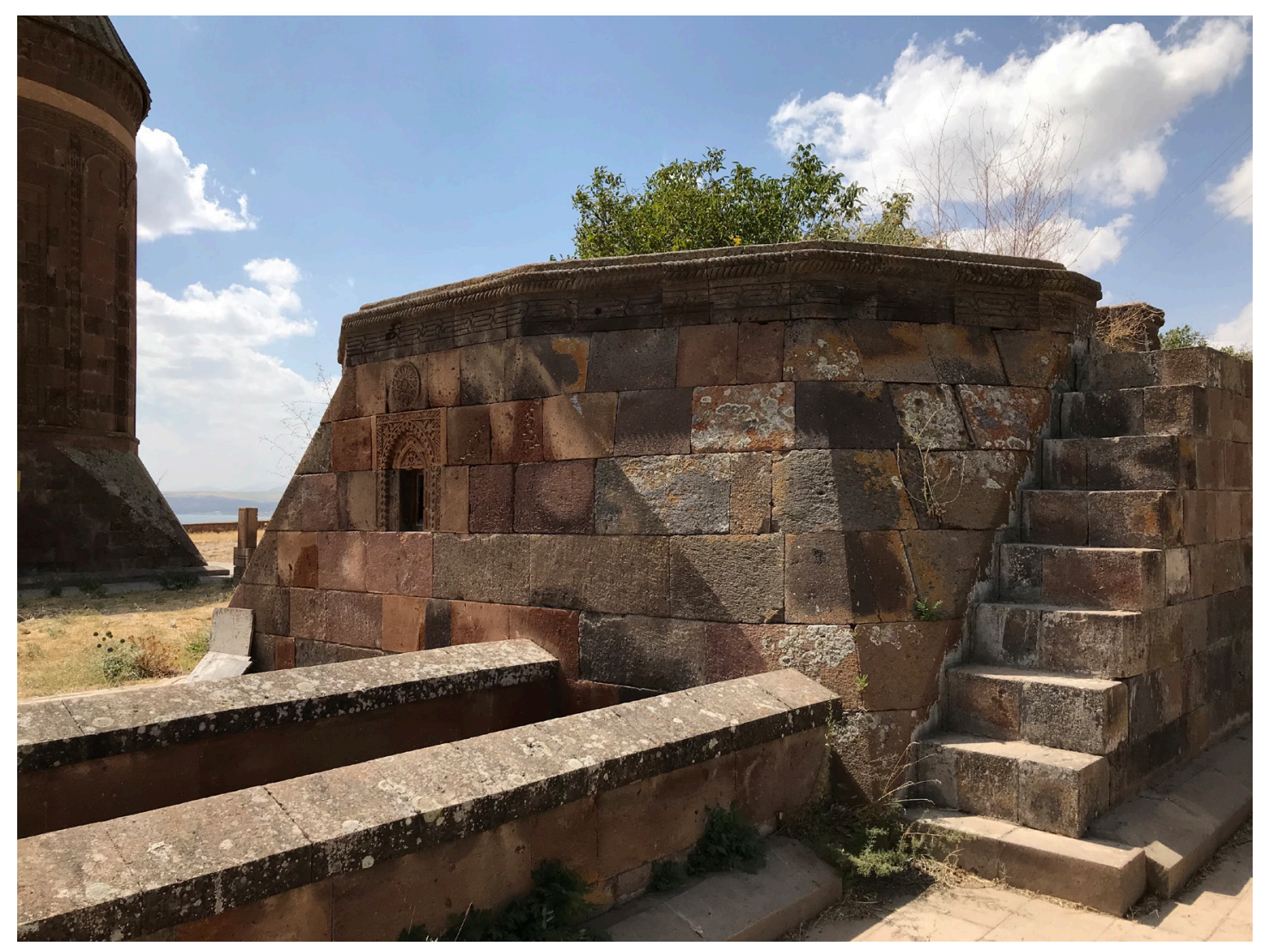

Fig. 8: Base of a tomb tower near Hasan Padişah, view showing stairs and entry to crypt constructed in restoration work (photo by the author, September 2018)

73 Gabriel, Şarki Türkiye'de Arkeolojik Geziler, 214; Tabak, Ahlat, 17; Tuncer, Anadolu Kümbetleri, 79; Uluçam, Bitlis, 216-217; Önkal, Anadolu Selçuklu Türbeleri, 198-200. 
About 300 meters to the northwest of this pair is another tomb tower, also in a partial state of preservation and thus anonymous (Fig. 4). Known as the Alimoğlu tomb, its cylindrical body is preserved up to the level of the window lintels on the cylindrical body. ${ }^{74}$ Both the form and the decorative repertoire of this tomb tower allow it to be dated approximately to the same period as the Hasan Padişah. Although it has been suggested that the Alimoğlu may have been an unfinished tomb tower, examination of the masonry and the rubble fill conducted during the restoration project was interpreted as evidence of collapse. Unlike the collapsed blocks of the Hasan Padişah, which were mostly found in situ, however, the site of the Alimoğlu tomb yielded no such blocks. ${ }^{75}$ As it stands, the Alimoğlu tomb appears not to have had a nearby companion tomb like the other Ilkhanid tomb towers in Ahlat, but this observation has not been corroborated by a systematic survey of the area.

Due south of the Meydanllk cemetery, about halfway from there to the lakeshore, is the grandest of Ahlat's late thirteenth-century tomb towers. Known locally as the Usta Şagirt ("Master Apprentice«) tomb, it is slightly larger than the Hasan Padişah tomb and is located on open flat land (Figs. 4, 9-10). ${ }^{76}$ It is considered to be Ahlat's finest tomb tower on the basis of the quality of its construction and decoration, as well as the grandeur that it imparts through its fine proportions. Its architecture and decoration are similar to Hasan Padişah and, because it does not have an inscription giving a name or a date, this similarity is used to date the Usta Şagirt tomb to the 1270s. A blank panel is found at the doorway on the north side, below the muqarnas niche, probably intended for an inscription that was never carved. A Quranic inscription is carved into white stone circling the tower just below the three-tier muqarnas frieze of the cornice. This inscription consists of the Throne Verse followed by the consecutive verse declaring the absence of compulsion in religion (2:255-256).

74 Gabriel, Şarki Türkiye'de Arkeolojik Geziler, 214; Tabak, Ahlat, 23; Tuncer, Anadolu Kümbetleri, 92-95; Uluçam, Bitlis, 219-222; Önkal, Anadolu Selçuklu Türbeleri, 202-203. The name of the tomb is alternatively given as Alimoğlu, Alimoğlu Hurşid, or Elimoğlu, but it is unclear what the source of this name is. Tabak mentions that it is also known with the name "Karaşı."«

75 It may be that the collapsed tomb tower was mined for its building blocks, perhaps used in the construction of the several houses in this area or elsewhere. These observations were made by Orhan Cezmi Tuncer who carried out the restoration project. Nevertheless, the idea of an incomplete tomb tower persists in the scholarship; see Önkal, Anadolu Selçuklu Türbeleri, 202-203.

76 Bachmann, Kirchen und Moscheen, 60-62; Beygu, Ahlat Kitabeleri, 87; Gabriel, Şarki Türkiye'de Arkeolojik Geziler, 211; Tabak, Ahlat, 12-14; Tuncer, Anadolu Kümbetleri, 70-75; Uluçam, Bitlis, 207-211; Önkal, Anadolu Selçuklu Türbeleri, 193-196. The alternative name of this tomb tower is Ulu Kümbet (»Great Tomb Tower«). 


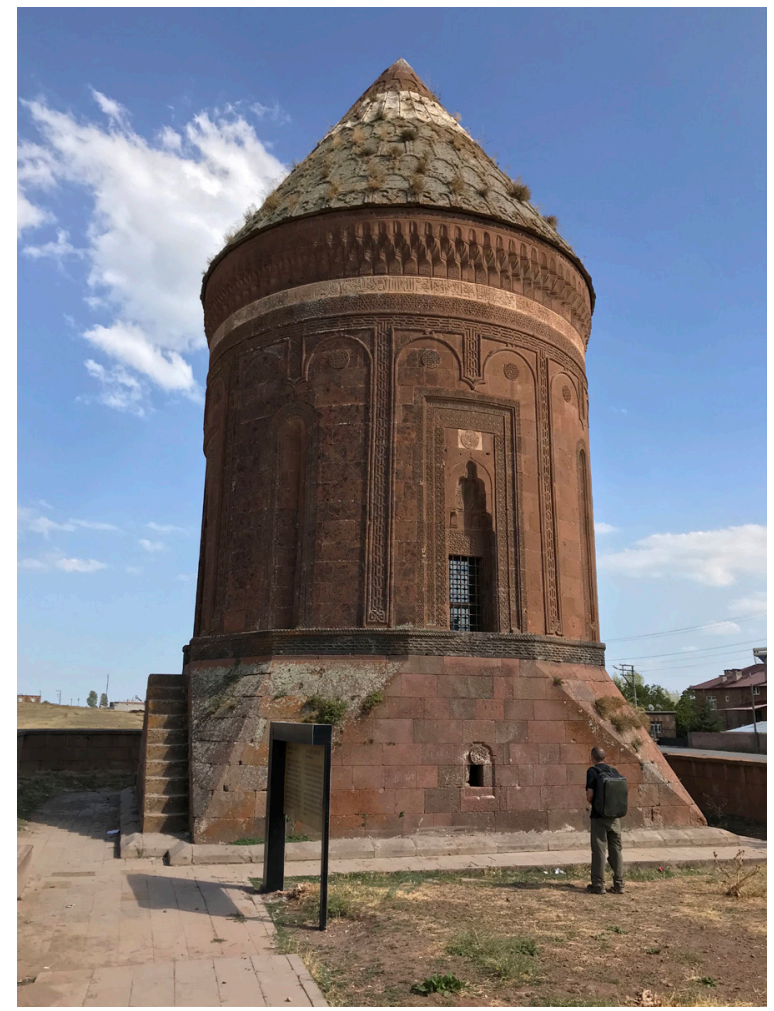

Fig. 9: Usta Shagirt tomb tower, view from the west (photo by the author, September 2018)

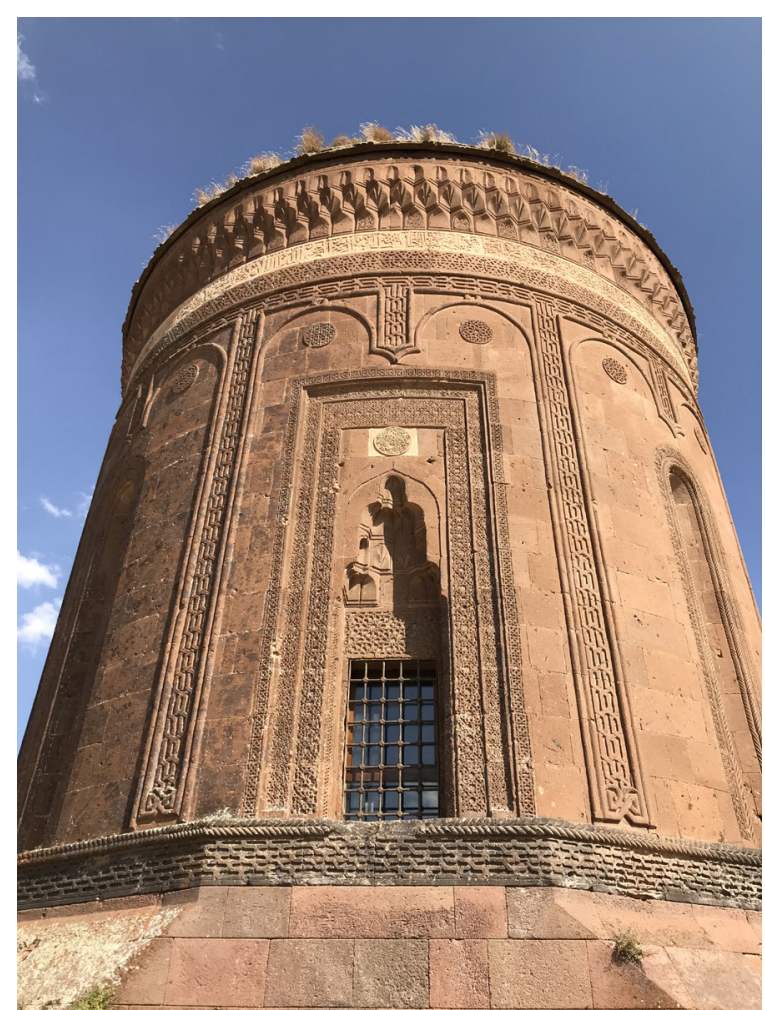

Fig. 10: Usta Şagirt tomb tower, view from the south (photo by the author, September 2018) 
A second tomb tower nearby is documented as having collapsed at the end of the nineteenth century. The British traveler H. F. B. Lynch, who visited Ahlat in 1898, reported that the ruins of this tomb tower were visible and that its inscription had been recorded by a local khoja before its collapse two years previously. Lynch transmitted the name in the inscription as "the great and noble Amir, Shadi Agha, son of the great Amir, Saughur Agha, son of Khaghan Agha" and its date as "A.H. 672 or A.D. 1273. «" Abdürrahim Şerif Beygu, who published the first and somewhat systematic recording of the inscriptions of Ahlat in 1932, claimed to have seen the pieces of this inscription among the stone blocks of the collapsed tomb tower. ${ }^{78}$ Beygu published the following reading of an apparently three-line inscription: lammā intaqala al-marḥūm al-shāb al-qașir al-'umr al-muhtāj ilà raḥmat Alläh ta'ālā / amìr Shādì [Shādhī] Särghūr Āqà ibn [Hāghān] Jāghān Āqā / tuwuffiya fì shahr [...] sana sab'mi'a. ${ }^{79}$

Although the two readings concur on the sequence of names (Shādì - Saughur/Sārghūr Khaghan/Ḥāghān/Jāghān), Lynch's reading gives three generations of a family, while Beygu's reading awkwardly joins the first two names, producing only two generations. ${ }^{80}$ Beygu's reading of an eighth-century Hijri date is unconvincing, while Lynch's specific year reading of 672/1273-1274 is more credible and corresponds to the Usta Şagirt's 1270s dating made in stylistic comparison with the Hasan Padişah tomb. The identities of Shādī Āqã and his predecessors remain unknown. ${ }^{81}$

77 Lynch, Armenia, 290.

78 Beygu, Ahlat Kitabeleri, 87. Beygu also reported that this tomb tower collapsed thirty-six years earlier, coinciding with the date of 1896 given by Lynch.

79 This can be translated as "when the deceased youth of short life, in need of God's mercy, Amir Shādī Sarghūr Āqā, son of Jāghān [Ḥāghān] Āqā, died in the month of ... the year seven hundred.«

80 It is entirely possible that Beygu (or the typesetters of this rather modest publication) unintentionally left off the word $i b n$ or bin ("son of ") between Shādī and Sarghūr Āqā. In any case, the three-generational sequence of names in Lynch's reading appears to be more correct than Beygu's two-generational sequence.

81 A contemporaneous Shādī Āqā or Shādī Küregen is named in the sources as a son of Sunjāq Āqā and the husband of Hülegü Khān's granddaughter Urgudaq/Orqudaq (hence the title küregen, meaning »son-in-law«); see Melville, Fall of Amir Chupan, 14-15; Zhao, Marriage as Political Strategy, 141. Sunjāq Āqā, also known as Suqunjāq or Su'unchāq Noyan, was "senior amir, yarghuchi and the commander of the right wing of Hülegü's army, as well as the military governor of Iraq and Fars under Abaqa Khan « (Yıldız, Post-Mongol pastoral polities, 31 n. 22). Sunjāq Āqā was a grandson of Chila'un or Chila'ugan, one of the four trusted generals of Chinggis Khān. On the family of Sunjāq Āqā, see also İlimli Usul, İlhanlı Döneminde Uygurlar, 128-135 (where a third variant of the name Sunjāq is given as Suqunjār). Although these names, apart from Shādī, do not exactly match the names transmitted by Lynch and Beygu, they may still be entertained as possible mutations of those names. Thus, Sārghūr/Saughur may be a distant echo of Sunjāq/Suqunjāq/Su'unjāq/Suqunjār and, somewhat more plausibly, Beygu's Jâghân may be considered as an avatar of Chila'un/Chila'ugan. The discrepancies could perhaps be explained as the effect of a threefold "translation, « first by way of the multiplicity of Persian and Arabic variants of Mongol and Turkic names, second by the creator of the inscription producing a version in Arabic script and inevitably introducing his own peculiarities of transcription, and third by Lynch's khoja and Beygu deciphering these names from the Arabic script. Considered from this perspective, these names could easily be »lost in translation. "However, three more issues can be cited in connection with this hypothetical identification. One is the Ilkhanid vizier Rashid al-Din's mention of the death of Sunjāq Āqā together with his son Shādī in Maragha, in 1290 (thus, seventeen years after the date of the inscription; Rashìd al-Dīn, Jami'u't-tawarikh, trans. Thackston, 573). A second issue concerns the questionability of including names of non-Muslim ancestors (as Chila'un most certainly was not Muslim) in a funerary inscription where the Islamic faith is claimed. The third and least problematic issue is that the inscription, in both readings, omits a generation between the would-be Sunjāq Āqã and Chila'un, but this may be explained by the prestige of having Chila'un as an ancestor; indeed, omitting an intermediate generation is not unheard of in inscriptions. 
Although the local name "Usta Şagirt" is now applied exclusively to the standing tomb tower at the site, Beygu reported that this dual appellation was used to refer to the pair of tomb towers. Lynch, for his part, did not record the local name of the standing tomb tower (referring to it only as the »isolated tomb «) but relayed a local tradition about the relationship between the two towers that expounds on the dual appellation. According to this tradition, the two tomb towers were built for two brothers. The elder brother's tomb tower - identified as the collapsed one - was evidently inferior (the work of an architect as "apprentice«) to the younger brother's more accomplished example (the work of a "master «) and caused the jealous elder brother to punish the architect by having his right hand cut off. While the story is likely a later invention based on the trope of architectural jealousy, the association of the two tomb towers with members of a single family is plausible, as is some kind of a dramatic or violent turn of events linked to the second one, which would explain the absence of the inscription naming its intended or actual occupant.

A third pair of tomb towers was built in Ahlat within six years of Hasan Padişah (Figs. 4, 11-12). Located about one and a half kilometers to the east of the Meydanllk cemetery, the two tomb towers are locally known by their paired name of İki Kubbe (»Two Domes«) or Çifte Kümbet (»Paired Tomb Towers«). ${ }^{82}$ The two monuments conform to the formal aspects of the Hasan Padişah and Usta Şagirt tomb towers in terms of their basic cylindrical form and the cardinal positions of their respective doorways on the north side and three windows on the east, south and west sides but also depart in certain respects such as the absence of elongated niches on the exterior of the cylindrical body. The earlier tomb tower is dated 1279 and gives the name of one Husayn Timūr, son of Būghātāy Āqā and indicates that he was »killed in the path of God" (qutila fi sabil Alläh) in the month of Rajab 678 (November 1279). The apparently violent nature of Husayn Timür's death also resonates with the designation of this tomb as a mashhad in the inscription. Both Ḥusayn Timūr and his father Būghātāy Āqà are titled "great amir" (al-amir al-kabir). Another inscription, this one installed above the eastern window, names Isān Tiginn, daughter of the "great amir« Ḥusām al-Dīn Ḥusayn Āqā, and gives the date of Shawwāl 678 (February 1280). Husayn Timūr and Isān Tiginn evidently died within three months of each other; that the latter may have also met a violent end is suggested by the epithet al-shahida but the remainder of the inscription is not as explicit on this matter. ${ }^{83}$ Isān Tiginn's relationship to Husayn Timūr is not established by either of the inscriptions, but a common assumption is that she was his wife.

82 Bachmann, Kirchen und Moscheen, 62-63; Beygu, Ahlat Kitabeleri, 72-73; Gabriel, Şarki Türkiye'de Arkeolojik Geziler, 211-212, 274-275; Tabak, Ahlat, 18-20; Tuncer, Anadolu Kümbetleri, 83-91; Uluçam, Bitlis, 231-239; Önkal, Anadolu Selçuklu Türbeleri, 186-192. İki Kubbe is also the name of the neighborhood east of the Meydanlı cemetery and north of the Ottoman lakeshore citadel, an indication of the significance of these two tomb towers in the evolving urban fabric of post-medieval Ahlat.

83 The epithets shahid and shahida appear very frequently on medieval Islamic funerary inscriptions. The term mashhad is a noun of place derived from the same root, $s h-h-d$, with the basic meaning of "witnessing." While these terms may indicate the specific condition of martyrdom, it is likely that they were also applied in a much more inclusive way in tomb inscriptions mainly to underscore the Muslim faith of the deceased, understood as an upholder of the Muslim confession of faith, the shahäda, a term likewise derived from the same root. The range of applications of these interrelated terms in a funerary context was first noted by Max van Berchem; see Blair, Monumental Inscriptions, 86. 
Located just several meters to the east of the Husayn Timūr-Isān Tigin tomb tower is a slightly larger but quite similar tomb tower. The inscription over its doorway dates the death of Būghātāy Āqā two years to the month after his son Ḥusayn Timūr, in Rajab of 680 (October 1281). Although the inscription does not explicate the nature of his death, the tomb is once again referred to as a mashhad and Būghātāy Āqā, too, is afforded the epithet al-shahid. Moreover, the inscription gives the name of his deceased father, one İnāl Āqā styled as al-amìr (rather than al-amir al-kabir). A second inscription, this one over the western window, gives the name of a Shīinn Khātūn, daughter of 'Abdāllah, along with the same date as for Būghātāy $\bar{A} q \bar{a}$, who is assumed to be her husband. As in the case of the other three inscriptions, here too the epithet al-shahida is applied, which, along with the concurrence of the date of Rajab 680, may be indicative of the same cause of (possibly violent) death for both Būghātāy Āqã and Shīrin Khātūn. Her father's name Abdāllah likely indicates her non-Muslim family background that may have been Christian or perhaps Buddhist.

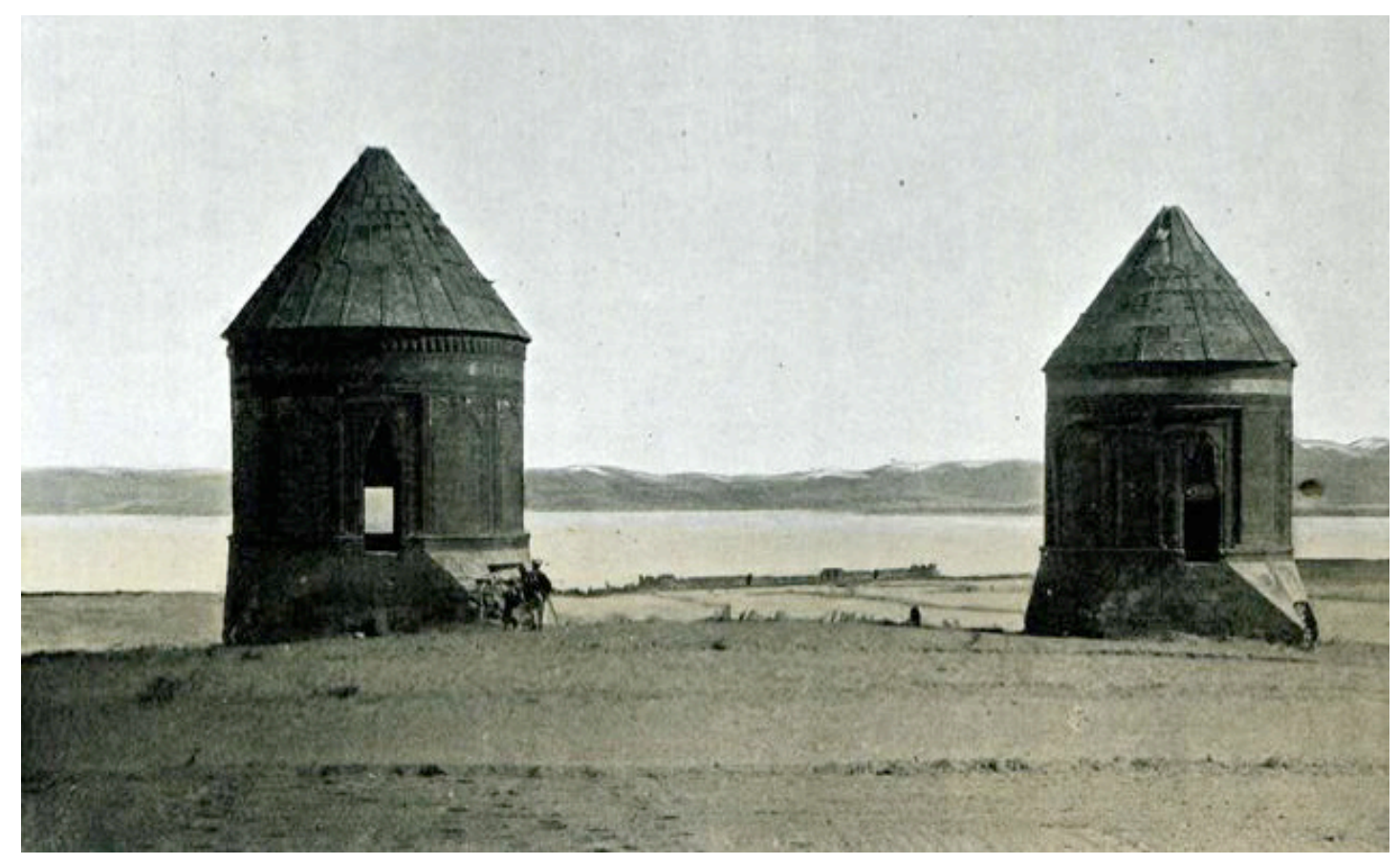

Fig. 11: İki Kubbe tomb towers, view from the north with the Ottoman citadel in the distance (source: Lynch, Armenia, 285) 


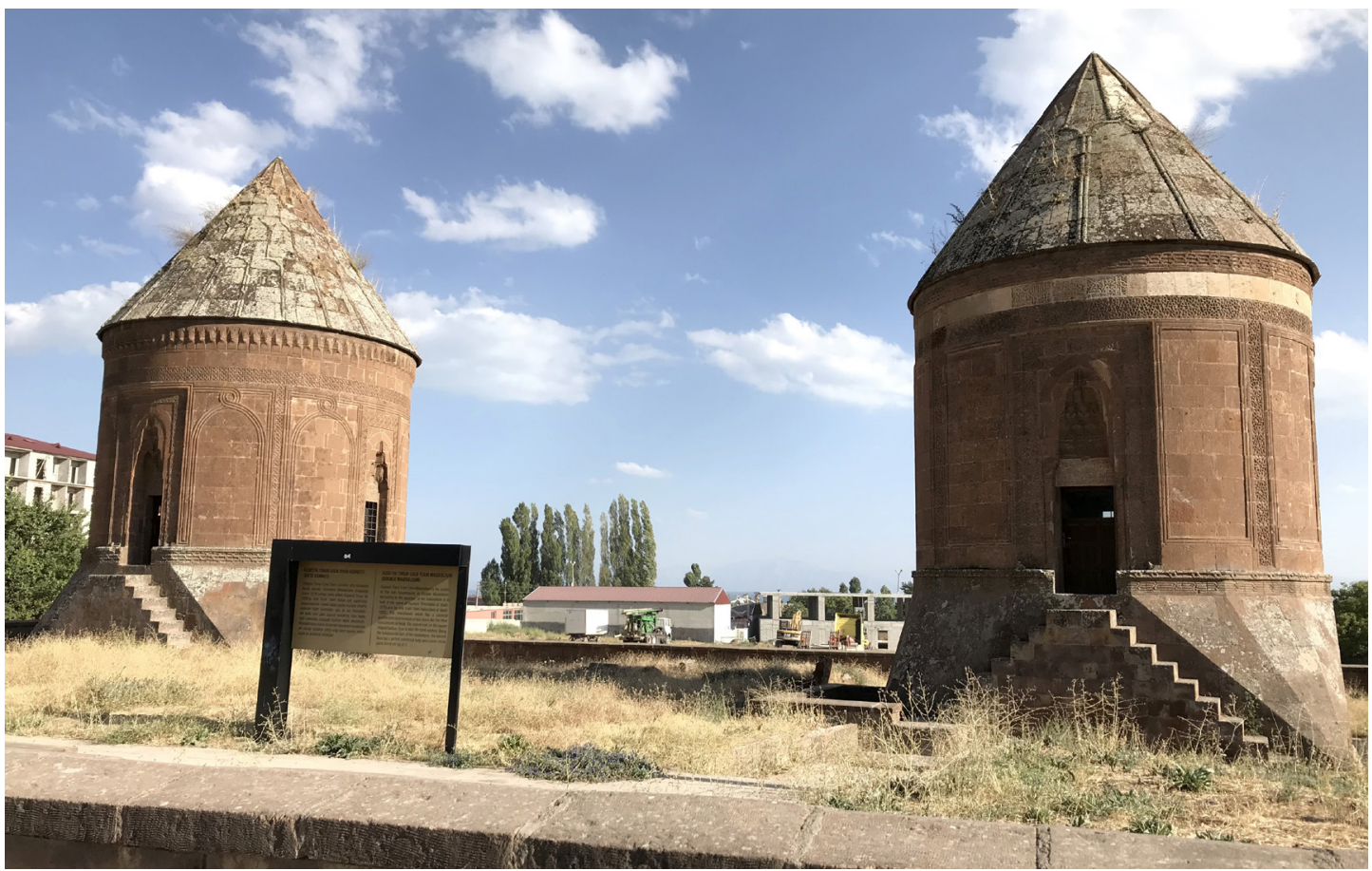

Fig. 12: İki Kubbe tomb towers, view from the north (photo by the author, September 2018)

The Būghātāy Âqā-Shīrinn Khātūn tomb tower is the last dated funerary monument to be built in Ahlat for an Ilkhanid amir. It is, however, architecturally very similar to a tomb tower built nine years later in Güroymak (formerly known as Norşin and Çukur), a settlement about 70 kilometers west of Ahlat. The inscription of this tomb tower names Qarandāy Āghā, styled al-amir al-kabir malik al-umarä' (»the great amir [and] king of amirs «) and gives his date of death as the fifth of Sha'bān 689 (13th August 1290). ${ }^{84}$ Unlike the Ahlat inscriptions, which name two or three generations of a family, the inscription in Güroymak is silent on Qarandāy Āghā's father or grandfather. In the phrase following his name, the inscription states that "he passed from the abode of annihilation (där al-fan $\bar{a}$ ) to the abode of mercy and subsistence (där al-baqä' wa'l-rahma) [as] a Muslim and a proclaimer of the unity of God (muwahhid). « ${ }^{85}$ This emphasis on his confessional state, coupled with the omission of his father's name, strongly suggests that Qarandāy Āghā was himself a convert to Islam. Constructed about a decade after the İki Kubbe tomb towers, the Qarandāy Āghā tomb is clearly the product of the same architectural workshop or venture, transplanted to a nearby town. The remains of the lower part of another tomb tower located to the south of the Qarandāy Āghā tomb shows that the pattern of paired tomb towers observable in Ahlat also applies here. ${ }^{86}$

84 Ünal, Doğu Anadolu Künbetleri, 124-128; Tuncer, Üç Kümbet, 94-8; Önkal, Anadolu Selçuklu Türbeleri, 196-198; Uluçam, Bitlis, 266-269. The Qarandāy Āghā tomb was in a partial state of preservation but was restored in the late 1960s. In addition to its similarity to the Būghātāy Āghā tomb, the Qarandāy Āghā tomb can also be related to the Alimoğlu tomb in Ahlat as both structures were furnished with an interior lunette in the form of a shell over their southern window.

85 Evidently, the inscription has a grammar mistake: the words muslim and muwahhid are active participles used as adverbs and as such should have taken the accusative case (musliman and muwahhidan).

86 Uluçam, Bitlis, 270. The same cemetery is noted as containing the remains of two more tomb towers, of which both the upper and lower parts have collapsed; Tuncer, Üç Kümbet, 94. 
Virtually nothing is known about these amirs, except for what is reflected in the surviving inscriptions on the tomb towers. On the basis of their names and the frequent use of the title $\bar{a} q \bar{a}$, they can be presumed to have Mongol or Turkic backgrounds, but it is not easy to distinguish between these two groups by name alone. ${ }^{87}$ While names such as İnāl or Isān Tigin appear to point to a Turkic ethnicity, other names such as Būghātāy are more difficult to pin down on the spectrum of Turko-Mongol naming conventions. According to the lineage given in the inscriptions on the tombs, the deceased were mostly second- or third-generation Muslims. In the example of Ḥasan Āqā and his father, Maḥmūd, the names seem to represent a "closed case " of Muslim identity where the only hint of Mongol or Turkic ethnicity is vested in the title $\bar{a} q \bar{a}$. By contrast, none of the names given in the now lost inscription of Shādi Āqã are manifestly Muslim names, but the very fact that they are declared in the inscription implies that Shādī Āqā's father (and grandfather, per Lynch) also professed Islam, placing the Islamization of this family somewhere around the middle decades of the thirteenth century. Similarly, the fact that Būghātāy Āqā's own father, İnāl Āqā, is named in his inscription indicates adherence to Islam in this particular family possibly as far back as the $1240{ }^{88}$ From a normative perspective, if any of these named members of earlier generations had not been Muslims, one would expect their names to have been either omitted or substituted by the telltale 'Abdallāh. The latter case applies to Shīinn Khātūn, the probable wife of Būghātāy Āqā. The former case can be observed in the inscription of the Qarandāy Āghã in Güroymak. Unlike the amirs in Ahlat, Qarandāy Āghā was himself a convert to Islam.

Although it is impossible to know for certain, it is quite likely that some of these amirs came from families that previously adhered to Buddhism. Up until the conversion of Ghazan Khan in 1295, the Ilkhanid royal family by and large adhered to the Buddhist faith, with the notable exceptions of certain prominent royal women who were Nestorian Christians and of the short reign of the Ilkhan Ahmad Tegüder (r. 1282-1284) who had become a Muslim as a prince. ${ }^{89}$ Abaqa Ilkhan, the reigning Ilkhan at the time that Ahlat tombs were constructed, was a Buddhist, as was his father, Hülegü, the founder of the Ilkhanate in Iran and Iraq. The association of the Ahlat amirial families with Islam thus predates the first instance of royal Ilkhanid acceptance of Islam by Ahmmad Tegüder by about four decades. It is also earlier than the earliest royal Mongol conversion, that of Berke Khān, Jochid ruler of the Golden Horde between 1257 and 1267, which is said to have occurred before his accession to the throne. Thus, chronologically speaking, at the time that the tomb towers were built, these amirs, with the notable exception of Qarandāy Āghā in Güroymak, had at least a few decades of familial engagement with Islam.

87 Morgan, Āqā.

88 This calculation is made by estimating that, at the time of his death in 1279, Būghātāy Āqā’s son Huusayn Timūr may have been around the age of twenty (that he was not a minor is suggested by the title al-amir al-kabir). Assuming that Būghātāy Āqā himself was at least twenty years old when his son was born (c. 1260), this would put Būghātāy Āqā's birth year around 1240. Because the inscription mentions Būghātāy Āqā’s father, it seems reasonable to assume that İnāl Āqā had become Muslim either before his son's birth - in which case the Islamization of the family may even go back to a date before c. 1240 - or that the family had adopted Islam while Būghātāy Āqā was a child in the 1240s. Two of the names at the İki Kubbe - İnāl and Isān Tikin - suggest a Turkic rather than Mongol identity.

89 Bausani, Religion; Prazniak, Ilkhanid Buddhism; Pfeiffer, Reflections; Deweese, Islamization; Grupper, Labnasagut; De Nicola, Women in Mongol Iran, 182-241. 
It seems fairly certain that the adoption of Islam by these amirial families predated the establishment of the Ilkhanate. Although their names have not been encountered in the narrative sources of the period, the period of their assumed conversion - middle of the thirteenth century - coincides with the Dominican friar Simon de Saint-Quentin's visit to the chief Mongol military commander Baiju in 1248, upon which he reported that Islam had gained ground among the military ranks of the Mongols..$^{90}$ This early, pre-Ilkhanid, phase of the Islamization of Mongol amirs appears to coalesce around the figure of Baiju, with reports mentioning the Muslim identity of the general's advisers and even claiming his own conversion to Islam on his deathbed. Based primarily in the Mūghān region of Transcaucasia, Baiju led the Mongol armies into Anatolia multiple times from the capture of Erzurum in 1242 and the Battle of Kösedağ in 1243 to the campaign of 1256 that brought the Mongol armies all the way to Aksaray and Konya. Although the Islamization of Mongol amirs has also been associated with their involvement in Anatolia, ${ }^{11}$ any direct effect of Anatolia in this respect probably occurred after the invasion of 1256 and especially after the imposition of direct Ilkhanid control in $1277 . .^{92}$

Given that the forebears of the Ahlat amirs seem to have adopted Islam by the 1240 s, it may be that their early Islamization is connected with the orbit of Baiju. This would also coincide with Baiju's capture of Ahlat in 1244-1245, ${ }^{93}$ but there is no evidence that any of the earlier generations named in the inscriptions were based in or otherwise linked with Ahlat at that time. However, as T'amt'a was installed almost immediately as the nominal ruler of the city, it is possible that some Mongol troops were also stationed here at the same time to ensure the alignment of Ahlat with Mongol interests. When considered in connection with T'amt'a's reported attempt to broker a marriage alliance between herself and the Ayyubid ruler of Mayyāfäriqin, the possibility of the introduction of some degree of Mongol military presence in Ahlat from the late 1240 s becomes a justifiable, albeit unverifiable, idea. Speculating further, it can be proposed that the political shifts effected by Hülegü's execution of Baiju around 1260 and the Ilkhanid-Jochid war starting in 1261-1262 would have had some repercussions for any amirs previously associated with Baiju, whether in Ahlat or elsewhere. The Ilkhanid-Jochid war was, at least in part, a contestation between the two Chinggisid rulers Hülegü and Berke Khan (r. 1257-1267) over territories in Transcaucasia and Anatolia. ${ }^{94}$ Berke Khan, the first member of the Chinggisid family to embrace Islam, ${ }^{95}$ apparently railed against Hülegü's 1258 campaign in Iraq that culminated in the conquest of Baghdad. The ultimate outcome of the conflict was the end of the unified Mongol empire. It may not be

90 Jackson, Mongols and the Islamic World, 338-340.

91 Jackson, Mongols and the Islamic World, 339-340; Pfeiffer, Reflections, 375-376.

92 Although the Mongol invasion of 1256 is described as a "large-scale movement of people« (Melville, Anatolia under the Mongols, 61), designed »to ease pressure on the grasslands of western Iran " prior to the coming of Hülegü Khān (Jackson, Mongols and the Islamic World, 126), it seems that Mongol military presence in Anatolia was a limited affair through the 1260s; Melville, Anatolia under the Mongols, 62.

93 Jackson, Mongols and the Islamic World, 84.

94 Jackson, Mongols and the Islamic World, 142-148.

95 Jackson, Mongols and the Islamic World, 348-349.

medieval worlds $\bullet$ No. $14 \cdot 2021 \cdot 117-154$ 
too farfetched to suggest that it was Hülegü who may have created or confirmed the Ahlat connection of the amirial families whose names are pronounced in the inscriptions and that their positions became consolidated under Abaqa Ilkhan. The Turkic inflection of some of the amirial names in Ahlat also strengthens the possibility of their link to Hülegü who came into Iran with an army that consisted of large numbers of Turks. ${ }^{96}$ Ultimately, Ahlat's geostrategic importance must have increased in Ilkhanid eyes starting with the retreat from Syria in 1260. Hülegü's stay in Ahlat on his way back to Transcaucasia may reflect this shift.

\section{Ahlat Inside Out: Suburban Agencies around a Compromised Urban Center}

The tomb towers built in Ahlat between 1273 and 1281 and in Güroymak in 1290 present a remarkably cohesive picture of monumental funerary architecture, representing the amirial families embedded in the Ilkhanid domination of Ahlat and the surrounding region during the reign of Abaqa Ilkhan. The visually dominant cylindrical forms of the surviving tomb towers lend this group a unified appearance that was probably intentional on the part of the patrons and was made possible by the availability and organization of skilled builders and stonemasons for two decades. This unified appearance, combined with the pattern of paired construction, distinguishes the Ahlat-Güroymak tomb towers as an exceptional paradigm in the medieval funerary architecture of Iran, Azerbaijan and Anatolia. They may be considered as the outcome as much of the particular identities of the patrons and the political circumstances in which they operated as of the peculiar matrix of Ahlat's resources and fissures towards the end of the thirteenth century.

The relationship of the amirs named in the inscriptions to the city of Ahlat can be explored by taking note of the pattern of the paired construction of the tomb towers along with their peripheral locations. The question of whether the pairing of the tomb towers held a particular symbolic or functional meaning is difficult to answer. It may be significant that the addition of double minarets flanking portals had first emerged in Anatolia around 1258, probably as an idea imported from Iran or Azerbaijan, and became a trend towards the end of the century in cities such as Sivas. ${ }^{97}$ Apart from visually augmenting the monumentality of the portals of mosques and madrasas, it is not known if these double minarets had any specific function or meaning. In the case of the Ahlat tomb towers, the pairing of the tomb towers seems to have less to do with visual symmetry and emphasis and more with the intention to consolidate the position of amirial families by grouping their funerary monuments in discrete locations. Of the three pairs of tomb towers, the İki Kubbe tomb towers, where two generations of amirs and women from their families were interred, represent a most explicit case of family-based consolidation of dominance. The anecdotal evidence for the Usta-Şagirt tomb also points in the direction of a family connection between the two tomb towers. While nothing can be deduced from the partially surviving companion tomb tower to Hasan Padişah, a family connection likely applied to that pair as well. Through their inscriptions, the tomb towers presented the Muslim lineage of the amirs, accentuating further the concept of family as a corporation that was also embodied by the paired monuments.

96 Lane, Early Mongol Rule, 19.

97 The earliest example of a portal flanked by minarets is the Sahib Ata mosque in Konya (1258). The idea was repeated in 1271 at two madrasas built in Sivas, the Gök Medrese and the Çifte Medrese. 
Interpreting the paired tomb towers as a visual consolidation of amirial families in the context of Ahlat also finds support in the seventeenth-century account of the Ottoman traveler, Evliya Çelebi. ${ }^{98}$ Although Evliya Çelebi's narrative on the historical background of Ahlat is riddled with confusion and conflation of events and names, his account of the tomb towers is noteworthy for reflecting the survival of a local emphasis on discrete family identities. Describing Ahlat as the place where the ancestors of the Ottoman, Danishmandid, Chobanid, Aqqoyunlu and Qaraqoyunlu dynasties first settled after their migration from Transoxiana $(M \bar{a} h \bar{a} n)$ on account of the "Tatar« depredations, Evliya Çelebi claims that the funerary monuments in Ahlat belong to the founding members of these families as well as to their wives. In line with his Ottoman bias, he attributes monumental domed tombs ( $k \imath b \bar{a} b-\imath$ azim) to Kuba Alp Bay, identified as the great-grandfather of Osman Bey, and his brothers and their wives. Furthermore, referring to each of the funerary sites as a separate ziyāretgāh (»place of visitation«), Evliya Çelebi accentuates the idea of corporate dynastic identities represented by their monumental funerary markers. Despite forcing a biased and distorted historical convergence of all of these dynasties in pre-Ottoman Ahlat, Evliya Çelebi effectively conveys the familial substance of the tombs which he relates as the main architectural highlight of a once-great city otherwise reduced to a morass of ruins (harābistān).

Although the location of the Ilkhanid tomb towers can be described as peripheral, little is known for certain about Ahlat's urban center in the late thirteenth century. It is probable that the ravine in between the medieval citadel and the Meydanlık cemetery - site of the so-called Harabe Şehir - continued to serve as a habitational and perhaps commercial area. The area to the north of the medieval citadel and the Meydanllk cemetery may have also functioned as an urban center of sorts, to judge by the ruins of the double bathhouse and the elusive remains of a mosque. In the current state of archaeological knowledge concerning these areas and the citadel itself, it is not possible to speculate further on the density or vitality of habitation through the thirteenth century. Nevertheless, the siting of the three pairs of tomb towers that form a triangle staking out the wider territory of these two contiguous clusters of probable urban habitation and their neighbor, the Meydanlık cemetery, reveals the endurance of their status as a spatial center. The locations of the tombs flank the presumed urban core of Ahlat on the west, south and east sides, forming an outer arc punctuated by the paired tomb towers. It seems reasonable to assume that the areas where the tomb towers were built were largely uninhabited and, furthermore, did not overlap with the locations of the suburban zāwiyas that can be traced from the Ottoman tax registers and from the still standing tomb of Şeyh Necmeddin in the eastern neighborhood of Ergezen. For their part, the zäwiyas appear to have marked the outer flanks of the city to the west, north and east. The northern hinterlands of Ahlat were also home to a number of Armenian rock-carved monastic sites. ${ }^{99}$ Together with the sites on which the tomb towers were built on the western, southern and eastern flanks, the outer perimeter of Ahlat was fully, albeit irregularly, staked out by the end of the thirteenth century.

98 Evliya Çelebi, Evliya Çelebi Seyahatnamesi, ed. Dağlı and Kahraman, 84-89

99 Bixio and De Pascale, Underground settlements, $128 .$. 
This complementary adherence of the zäwiyas and the tomb towers to the outer contours of Ahlat does not, however, mean that their status and functions were identical or even similar. The zäwiyas were embedded into waqf arrangements and served the function of socio-religious interaction within a variable framework of Sufi praxis. The very brief description of their functions in the Ottoman tax registers of the sixteenth century consists, without exception, of the stipulation that their incomes be spent for the provision of the needs of travelers (äyende ve revendeye sarf olunur). In this respect, the zäwiyas of Ahlat were no different from their numerous counterparts founded all across Anatolia in the thirteenth and fourteenth centuries. These zäwiyas were very frequently associated with the futuwwa organizations through which young men were initiated to brotherhoods that upheld precepts of chivalry and morality with a mystical or Sufi inflection. ${ }^{100}$ The members of futuwwa organizations were known as akhi or fatä (pl. fityān) and were subject to a process of hierarchical advancement within the brotherhood led by a shaykh. One of the things that distinguished the futuwwa brotherhoods from Sufi brotherhoods, especially in Anatolia, was their integral commitment to a professional life of craft production or trade. Typically, members of a futuwwa brotherhood maintained a "day job « as craftsmen or tradesmen, congregating in the evenings in their zâwiya for communal meals, rituals and the hosting of guests.

Although it is not possible to know for certain if some or all of the zäwiyas of Ahlat served futuwwa organizations, the presence of fityān in Ahlat is known from the historian Ibn al-Athir who noted them as the organizers of a regional anti-Ayyubid rebellion in the beginning of the thirteenth century. ${ }^{101}$ This brief mention reveals that one or more futuwwa organizations in Ahlat exercised local authority at a time of political uncertainty and transition. The precepts and practice of futuwwa in Anatolia also transcended religious boundaries, the most substantial evidence for this being the late thirteenth-century Armenian treatises written on the subject in the city of Erzincan, evidently with the purpose of bringing about moral and institutional reforms to Armenian brotherhoods. ${ }^{102}$ In fact, the existence of Armenian "futuwwa-like« brotherhoods has been traced as early as the 1120 s and to the region of Lake Van. ${ }^{103}$ Despite the absence of details on this early formation, cities like Ahlat where Armenian and Muslim (Arab, Iranian and Turkic) populations had a long history of encounter and coexistence would have provided the necessary conditions for the cross-cultural incubation of such organizations. Seen from this vantage point, the distribution of zāwiyas and Armenian monastic sites in the hinterlands of Ahlat suggests a parallel development reflecting similar socio-religious organizations in both communities.

100 Durocher, Akhi lodge; Goshgarian, Opening and closing; Pancaroğlu, Devotion, hospitality and architecture, 60-72.

101 Ibn al-Athïr, Chronicle, 137-138; Humphreys, Saladin to the Mongols, 129-130. Ibn al- Athï's observation is paralleled by a similar identification of the rebels by Bar Hebraeus; see La Porta, Legitimizing land and power, 87. The fityān organization of Ahlat may even go back to the period of the Shāh-i Arman rulers since Sayf al-Dīn Begtimūr was noted to adhere to a Sufi ethos; Ibn Shaddād, Rare and Excellent History, trans. Richards, 67.

102 Goshgarian, Futuwwa.

103 Goshgarian, Futuwwa, 234-235. 
Unlike the zäwiyas, the Ilkhanid tomb towers do not appear to have any civic or institutional associations or waqf frameworks, at least none that can be traced from the available evidence. There is no indication that any of the tomb towers were associated with another building such as a madrasa or a mosque. It seems reasonable to assume, therefore, that these funerary monuments mark lands granted to or otherwise expropriated by the Ilkhanid amirs, perhaps collectively at one time - for instance, upon Hülegü's retreat from Syria when he stopped in Ahlat - or sequentially over the course of a period. ${ }^{104}$ As apportioned lands in the western, southern and eastern flanks of the city, these could have served as the site of the amirs' encampment, including residential provisions for their households, in the typical pattern observed for medieval Turco-Mongol military and political leaders. ${ }^{105}$ Additionally, such apportioned lands may have incorporated gardens and the types of fruit orchards for which Ahlat was well known and may have also represented some form of economic asset. Although there is no information about their specific locations, Ibn Bībi made reference to "gardens of the city" (bäghha-yi shahr) in the context of the Rum Seljuq occupation of Ahlat in the early 1230 s and illustrated the use of one such garden to which a group Khwārazmian warriors active in the area of Tatvan were summoned to pay their allegiance to the Rum Seljuq authorities. ${ }^{106}$ Ibn Bïbì's account makes clear that the garden was in a suburban location to which the Rum Seljuq officials »descended « from the citadel, which they were in the process of repairing. Considering the direction of the Khwārazmian warriors' arrival from the direction of Tatvan in the west, the open flat land between the city and lake where the Usta-Şagirt tomb was later built, for instance, could be a likely location for the garden that served as the setting for the process of oath-taking spread over two days and celebrated by lavish feasts. Although there is no information on what kind of gardens surrounded Ahlat, at least some of them must have incorporated orchards producing the fruit which is a noted aspect of the city recorded in the geographical works of both Yàqūt al-Ḥamawi (completed in the 1220s) and Haamdallāh Mustawfi (completed c. 1340). ${ }^{107}$

Whether or not the sites of the tomb towers in Ahlat were indeed apportioned to the amirs by Hülegü or later by Abaqa Ilkhan, their immediate horizon was the territorial contestation and political fragmentation (or at least reorientation) of the 1260s. Seen from this vantage point, the particular aspects of the tomb towers built by and for the Muslim amirs emerge as a strategy of broad inclusivity. While laying claim to the city's flanks in line with both the pattern established by the influential institutional vector of the zâwiyas and the Turko-Mongol preference for the suburban setting, these monumental buildings also partook of an established Iranian-Anatolian tradition of tomb towers and, furthermore, reflected an alignment with the local Islamic predisposition to funerary investment as documented in the impressive tombstones of the Meydanlık cemetery.

104 On different cases of land grants and expropriation, see Amitai, Turko-Mongolian nomads, 156-157. On the Mongol practice of apportioning, see Allsen, Culture and Conquest, 43-49.

105 For the Great Seljuq practice, see Durand-Guédy, Ruling from the outside. For an example of contemporary Chaghataid Mongol practice in Central Asia, see Biran, Rulers and city life.

106 Ibn Bībī, El-Evāmirü'l-'Alā'iyye [facsimile edition], 430-432, trans. Öztürk, 430-431.

107 Yāqūt al-Ḥamawī, Mu’jam al-buldān, 380; Hamdallāh Mustawfì, Nuzhat al-qulūb, 100.

medieval worlds $\cdot$ No. $14 \cdot 2021 \cdot 117-154$ 
Indeed, the presence of highly competent and experienced craftsmen in Ahlat in the 1270 s and 1280 s and in Güroymak in 1290 is mirrored in the chronology of surviving tombstones in the Meydanlık cemetery that exhibit a revitalization of the stone carving industry in Ahlat starting around 1250 after a decline in production probably triggered by the Khwārazmshāh destruction in 1229. The beginning of this revitalization is signaled by the signature of an artisan named Ahmad al-Muzayyin who produced tombstones from 1249 to 1261 and whose epithet al-muzayyin, meaning »designer" or »decorator, « suggests that he applied his art to a variety of media. ${ }^{108}$ Among the subsequent signed tombstones are names of other craftsmen who were apparently related to Ahmad al-Muzayyin. Uways (or Ways) b. Ahmad, who produced tombstones between 1265 and 1275, is presumed to be Ahmad al-Muzayyin's son and the master of another craftsmen, Asad b. Ayyūb (active between 1277 and 1291), who signed some of his works as the apprentice (ghuläm and shäkird) of Uways b. Ahmad. ${ }^{109}$ Uways b. Ahmmad's two sons, Aṣil b. Ways and Muḥammad b. Ways, also continued in the profession of their father and grandfather. ${ }^{110}$ Așil $b$. Ways signed his earliest work from 1295 as the apprentice (shäkird) of Asad b. Ayyūb and evidently had a long and prolific career lasting at least until 1327. Among this group of craftsmen, the works of Asad b. Ayyūb stand out in terms of the novel features such as the muqarnas cornice and double-dragon motif that he evidently introduced to the design repertoire of the tombstones.

This sequence of craftsmen's signatures reveals the continuity in the production of tombstones in Ahlat by way of both family and master-apprentice transmissions that were patently recorded on the tombstones. In particular, the figure of Asad b. Ayyūb and his explicit master-apprentice relationships which can be traced from the signatures on the tombstones resonate remarkably with the expected ethos of craftsmen embedded in a futuwwa organization where initiation to the brotherhood paralleled initiation to a craft or trade. ${ }^{111}$ Although there is no solid evidence to link any of these craftsmen to any of the zāwiyas of Ahlat, both the zāwiyas and the signatures of the craftsmen point to the likely survival of the futuwwa brotherhoods that evidently had a prominent urban presence in Ahlat at least since the Ayyubid period. The endurance of the zawwiyas through the trials and tribulations of the thirteenth century and the additions to their numbers in the fifteenth century seem to reflect a long term urban modus vivendi predicated on the sustainability of social networks tangential to political stability or authority. In the case of the depredations suffered by Ahlat in the form of military assaults and severe earthquakes, the location of these zäwiyas on the outer perimeter of a partially or mostly impaired urban center indicate a spatial externalizing of urban agency. This is not to say that the former urban center became devoid of habitation or commerce but rather that the land around the urban center became the setting for the nexuses of socio-political and probably economic influence. In other words, through the course of the thirteenth century, Ahlat as an entity of urban vectors was, spatially speaking, turned inside out.

108 Karamağaralı, Ahlat Mezartaşları, 91-92, 130-131, 146-153.

109 Karamağaralı, Ahlat Mezartaşları, 92-95, 132-134, 136-137, 153-170.

110 Karamağaralı, Ahlat Mezartaşları, 95-58, 173-193.

111 Goshgarian, Opening and closing. 
It is probably not a coincidence that Asad b. Ayyüb's documented career between 1277 and 1291 overlaps significantly with the period in which the tomb towers were constructed. None of the tomb towers were signed by the craftsmen who executed them, but by correlating their construction with the production of tombstones, the 1270 s and early 1280 s in Ahlat emerge as a period of particularly dynamic artistic and architectural activity. The organization of this activity most likely involved the spheres of social, economic and spiritual influence emanating from the numerous zāwiyas and their established claim on the suburban land. Despite the lack of direct information regarding the connection between the zäwiyas and the presence of Ilkhanid amirs, their complementary claims on the outer contours of Ahlat suggests a synergetic relationship turning on the Muslim identities of the amirs. Such a relationship, though conjectural, makes sense in the context of the 1270 s and early 1280 s when conversion of Mongol amirs to Islam was picking up pace but when the conversion of the Ilkhanid royals had barely been triggered and the Buddhist sanctuary at Aladağ, located to the northeast of Lake Van, was still in its heyday. ${ }^{112}$ As presumed newcomers to Ahlat, the Muslim Ilkhanid amirs marked their presence at the perimeter of the city, inscribing their Muslim identity onto its immediate horizon and against the shifting political landscape of the early Ilkhanate. The construction of their tomb towers can be read as an initiative to establish a permanent physical presence while also linking to Ahlat's best asset, its craftsmen and their professional networks.

The ultimate purpose of the tomb towers built for the Ilkhanid amirs and their families in Ahlat appear not to have exceeded the function of memorializing their corporate identities in the local context. In this respect, they stand apart from later Ilkhanid funerary projects begun at the very end of the thirteenth century such as the Rab'-i Rashìdi of the vizier Rashìd al-Din or the Shanb-i Ghāzān of the Ilkhan Ghāzān - both constructed in the outskirts of Tabriz - in which the founder's tomb formed the nucleus of extensive waqf-secured socio-religious and commercial enterprises approximating small cities. ${ }^{113}$ These projects, however, were born of the impact of Ghazan Khan's conversion and the ensuing reorientation of the religious policies of the Ilkhans. As such, they signify the motivations of their founders - the bureaucrat and the king - to be associated with grand foundational projects combining Islamic institutions with funerary monuments and to endow them with their personal fortunes. The Ilkhanid amirs of Ahlat in the 1270 s and early 128 os would have had neither the prerogative nor, presumably, the means to undertake such grand institutional projects. Moreover, the institutional backbone of Ahlat was already constituted by the zäwiya networks that preceded the Ilkhanid domination and managed the process of socio-economic recovery. They did this not by rebuilding or reconstituting the urban fabric but by fostering a diffusely robust suburban environment attuned to and benefitting from agents of social and economic mobility. The Ilkhanid amirs may have been the new brokers of power, but they did not supplant the suburban agency of zāwiyas, opting instead to become privileged customers of exceptional artistic resources allowing them to imprint their identities on the edge.

112 Grupper, Labnasagut.

113 Hoffmann, Gates of Piety and Charity; Blair, Rab'-e Rašidi; Haneda, Pastoral city. 


\section{References}

Aksulu, Işık, Nakış Karamağaralı and Özlem Sağıroğlu, The Restitution of »Çifte Hamam« in Ahlat According to Final Excavation Outcomes, Gazi University Journal of Science 26 (2013) 489-500.

Allsen, Thomas T., Culture and Conquest in Mongol Eurasia (Cambridge, 2001).

Altunay, Emine, 1540 (H. 947) Tarihli Tahrir Defterine Göre Bitlis Sancă̆l. Unpublished MA thesis (Ondokuz Mayıs University, Samsun, 1994).

Ambraseys, Nicholas, Earthquakes in the Mediterranean and the Middle East: A Multidisciplinary Study of Seismicity up to 1900 (Cambridge, 2009).

Amitai, Reuven, Turko-Mongolian nomads and the Iqtă' system in the Islamic middle east (ca. 1000-1400), in: Anatoly M. Khazanov and André Wink (eds.), Nomads in the Sedentary World (Richmond, 2001) 152-171.

Amitai-Preiss, Reuven, Mongols and Mamluks: The Mamluk-Ilkhanid War, 1260-1281 (Cambridge, 1995).

Ananias of Shirak, The Geography of Ananias of Širak (AŠXARHAC'OYC'). The Long and the Short Recensions, translated from Armenian by Robert H. Hewsen (Wiesbaden, 1992).

Arslan, Celil, Ahlat Şehri Kent Dokusu ve Eski Eserleri, KARE-Uluslararası Edebiyat, Tarih ve Düşünce Dergisi 5 (2018) 1-21.

Arslan, Celil, Ahlat Kazılarının Dünü-Bugünü, Akdeniz Sanat Dergisi 13 (2019) [=21. Uluslararası Ortaçağ ve Türk Dönemi Kazıları ve Sanat Tarihi Araştırmaları Sempozyumu Bildirileri] 200-214.

Avşar, Ali Osman and Ahmet Güleç, Ahlat Selçuklu Meydan Mezarlığı Mezar Taşları Analiz Çalışmaları ve Konservasyon Önerileri, Restorasyon ve Konservasyon Çalışmaları Dergisi 1 (2019) 3-16.

Bachmann, Walter, Kirchen und Moscheen in Armenien und Kurdistan (Leipzig, 1913).

al-Balādhurī, The Origins of the Islamic State 1, translated from Arabic by Philip Khuri Hitti (New York, 1916).

Bausani, Alessandro, Religion under the Mongols, in: John A. Boyle (ed.), The Cambridge history of Iran, Volume 5, The Saljuq and Mongol Periods (Cambridge, 1968) 538-549.

Beygu, Abdurrahim Şerif, Ahlat Kitabeleri (Istanbul, 1932).

Biran, Michal, Rulers and city life in Mongol Central Asia (1220-1370), in: David DurandGuédy (ed.), Turko-Mongol Rulers, Cities and City Life (Leiden, 2013) 257-283.

Bixio, Roberto and Andrea De Pascale, Ahlat underground settlements research project 2007-2008-2009, in: Kadir Pektaş et al. (eds.), XIII. Ortaçağ ve Türk Dönemi Kazıları ve Sanat Tarihi Araştırmaları Sempozyumu Bildirileri (Istanbul, 2010) 123-130.

Bixio, Roberto, Andrea De Pascale and Andrea Bixio, Ahlat 2010: The fourth expedition to the Lake Van, Opera Ipogea: Journal of Speleology in Artificial Cavities 2 (2010) 3-26.

Blair, Sheila S., Monumental Inscriptions from Early Islamic Iran and Transoxiana (Leiden, 1992).

Blair, Sheila S., Rab'-e Rašidi, in: Encyclopædia Iranica (online edition, 2016). Accessed on 9 March 2016: www.iranicaonline.org/articles/rab-e-rashidi.

Bosworth, C. Edmund, Akhlāț, in: Kate Fleet, Gudrun Krämer, Denis Matringe, John Nawas, Everett Rowson (eds), Encyclopaedia of Islam, THREE. Accessed on 1 April 2020: dx.doi. org/10.1163/1573-3912_ei3_COM_23100. 
Canard, Marius, Claude Cahen and J. Deny, Arminiya, in: Peri Bearman, Thierry Bianquis, C. Edmund Bosworth, Emeri van Donzel, Wolfhart P. Heinrichs (eds), Encyclopaedia of Islam. Second Edition. Accessed on 4 April 2020: dx.doi.org/10.1163/1573-3912_islam_ COM_oo64.

Çal, Halit, Tapu Tahrir Defterleri ve Hurufat Defterlerine Göre Ahlat'da Türk Mimarisi, in: Hakkı Acun et al. (eds.), Prof. Dr. Haluk Karamağaralı Armağanı (Ankara, 2002) 71-86.

Dahiliye Vekaleti, Son Teşkilat-ı Mülkiyede Köylerimiz'in Adları (Istanbul, 1928).

Dashdondog, Bayarsaikhan, The Mongols and the Armenians (1220-1335) (Leiden, 2011).

De Nicola, Bruno, Women in Mongol Iran: The Khatuns, 1206-1335 (Edinburgh, 2017).

Demir, Ahmet, Ahlât Eyyûbîleri Tarihi (Istanbul, 2019).

Deweese, Devin, Islamization in the Mongol Empire, in: Nicola di Cosmo, Allen J. Frank and Peter B. Golden, (eds.) The Cambridge History of Inner Asia: The Chinggisid Age (Cambridge, 2009) 120-134.

Durand-Guédy, David, Ruling from the outside: A new perspective on early Turkish kingship in Iran, in: Lynette Mitchell and Charles Melville (eds.), Every Inch a King: Comparative Studies on Kings and Kingship in Ancient and Medieval Worlds (Leiden, 2013) 325-342.

Durocher, Maxime, Akhi lodge, Akhi architecture or Akhi patronage? Architecture of fotovvat-based associations in medieval Anatolia, in: Lloyd Ridgeon (ed.), Javanmardi: The Ethics and Practice of Persianate Perfection (London, 2018) 98-132.

Eastmond, Antony, Tamta's World: The Life and Encounters of a Medieval Noblewoman from the Middle East to Mongolia (Cambridge, 2017).

Evliya Çelebi, Evliya Çelebi Seyahatnamesi, 4, transcribed and ed. Yücel Dağlı and Seyit Ali Kahraman (Istanbul, 2000).

Gabriel, Albert, Şarki Türkiye'de Arkeolojik Geziler, translated from French to Turkish by İdil Çetin (Ankara, 2014).

Garsoïan, Nina, The Arab invasions and the rise of the Bagratuni, in: Richard G. Hovannisian (ed.), The Armenian People from Ancient to Modern Times, 1 (New York, 1997) 117-142.

Goshgarian, Rachel, Opening and closing: Coexistence and competition in associations based on Futuwwa in late medieval Anatolian cities, British Journal of Middle Eastern Studies 40 (2013) 36-52.

Goshgarian, Rachel, Futuwwa in thirteenth-century Rūm and Armenia: Reform movements and the managing of multiple allegiances on the Seljuk periphery, in: A. C. S. Peacock and Sara Nur Ylldız (eds.), The Seljuks of Anatolia: Court and Society in the Medieval Middle East (London, 2013) 227-263.

Grupper, Samuel M., The Buddhist Sanctuary-Vihārā of Labnasagut and the Il-Qan Hülegü: An overview of Il-Qanid Buddhism and related matters, Archivum Eurasiae Medii Aevi 13 (2004) 5-77.

Hamdallāh Mustawfi Qazvīnī, The Geographical Part of the Nuzhat-al-Qulūb, translated from Persian by G. Le Strange (Leiden, 1919).

Haneda, Masashi, The pastoral city and the mausoleum city: Nomadic rule and city construction in the eastern Islamic world, in: Tsugitaka Satō (ed.), Islamic Urbanism in Human History: Political Power and Social Networks (London, 1997) 142-170.

Hillenbrand, Carole, A Muslim Principality in Crusader Times: The Early Artuqid State (Leiden, 1990).

Hillenbrand, Carole, Marwānids, in: Peri Bearman, Thierry Bianquis, C. Edmund Bosworth, Emeri van Donzel, Wolfhart P. Heinrichs (eds), Encyclopaedia of Islam. Second Edition. Accessed on 4 April 2020: dx.doi.org/10.1163/1573-3912_islam_SIM_4983. 
Hillenbrand, Carole, Shāh-i Arman, in: Peri Bearman, Thierry Bianquis, C. Edmund Bosworth, Emeri van Donzel, Wolfhart P. Heinrichs (eds), Encyclopaedia of Islam. Second Edition. Accessed on 4 April 2020 dx.doi.org/10.1163/1573-3912_islam_SIM_6746.

Hoffmann, Birgitt, The Gates of Piety and Charity: Rašīd al-Dīn Fadl Allāh as founder of pious endowments, in: Denise Aigle (ed.), L'Iran face à la domination mongole (Paris, 1997) 189-202.Hübschmann, Heinrich, Die altarmenischen Ortsnamen (Strasbourg, 1904).

Humphreys, Stephen, From Saladin to the Mongols: The Ayyubids of Damascus, 1193-126o (Albany, 1977).

Ibn al-Athīr, The Chronicle of Ibn al-Athì for the Crusading Period from al-Kāmil fíl-ta'rīkh, Part 3: The Years 589-629/1193-1231. The Ayyubids after Saladin and the Mongol Menace, translated from Arabic by Donald S. Richards (Aldershot, 2008).

Ibn Bībī, El-Evāmirü'l-'Alā'iyye fî̀l-Umūri'l-'Alā'iyye [facsimile edition](Ankara, 1956), trans. Mürsel Öztürk, El Evamirü'l-Ala'iye fi'l-Umuri'l-Ala'iye (Selçuk Name) 1 (Ankara, 1996).

Ibn Shaddād, The Rare and Excellent History of Saladin, translated from Arabic by Donald S. Richards (Aldershot, 2002).

İlimli Usul, Dilber, İlhanlı Döneminde Uygurlar. Unpublished PhD thesis (Selçuk University Konya, 2016).

Jackson, Peter, Bāyjū, Encyclopaedia Iranica. Accessed on 26 April 2020: www.iranicaonline. org/articles/bayju-baiju-or-baicu-mongol-general-and-military-governor-innorthwestern-iran-fl.

Jackson, Peter, The Mongols and the Islamic World: From Conquest to Conversion (New Haven, 2017).

Kafesoğlu, İbrahim, Ahlat ve Çevresinde $1945^{`}$ te Yapılan Tarihi ve Arkeolojik Tedkik Seyahati Raporu, Tarih Dergisi 1 (1949) 167-200.

Karahan, Recai and Eylem Güzel, Eski Ahlat Şehri Kazıları (2011-2012), 35. Kazı Sonuçları Toplantısı, 1 (Muğla, 2014) 339-348.

Karahan, Recai, Mehmet Kulaz and Eylem Güzel, Eski Ahlat Şehri Kazıları (2013), 36. Kazı Sonuçları Toplantısı, 1 (Ankara, 2014) 499-510.

Karahan, Recai, Rahmi Tekin, Mehmet Kulaz, Selami Reisoğlu, İlter İgit, Mustafa Oral and Abdullah Alp, Ahlat Selçuklu Meydan Mezarlı̆̆ı ve Mezar Taşları (Ankara, 2019).

Karamağaralı, Beyhan, Ahlat Mezartaşları (Ankara, 1972).

Karamağaralı, Haluk, Ahlat Kazıları (1967-1991), in: Oktay Belli (ed.), II. Van Gölü Havzası Seтроzуити (Bitlis, 2007) 83-104.

Karamağaralı, Haluk, Ahlat'ta Bulunan Tümülüs Tarzındaki Türk Mezarları, Önasya 5 (1970) 59-60.

Kılıç, Orhan, XVI. Yüzyılda Adilcevaz ve Ahlat (1534-1605) (Ankara, 1999).

Koçak, Zülfiye, XVI. Yüzyıl Tapu Tahrir Defterlerine Göre Bitlis Camileri ve Mescitleri, Vakıflar Dergisi 51 (2019) 73-98.

La Porta, Sergio, >The kingdom and the sultanate were conjoineds: Legitimizing land and power in Armenia during the 12th and early 13th centuries, Revue des études arméniennes 34 (2012) 73-118.

Lane, George, Early Mongol Rule in Thirteenth-Century Iran: A Persian Renaissance (London, 2003).

Layard, Austen H., Discoveries among the Ruins of Nineveh and Babylon; with Travels in Armenia, Kurdistan, and the Desert (New York, 1853).

Lynch, H. F. B., Armenia: Travels and Studies, 2: The Turkish Provinces (London, 1901). 
Melville, Charles, The Fall of Amir Chupan and the Decline of the Ilkhanate, 1327-37: A Decade of Discord in Mongol Iran (Bloomington, 1999).

Melville, Charles, Anatolia under the Mongols, in: Kate Fleet (ed.), The Cambridge History of Turkey 1, Byzantium to Turkey, 1071-1453 (Cambridge, 2009) 51-101.

Minorsky, Vladimir, Studies in Caucasian History (London, 1953).

Minorsky, Vladimir and Franz Taeschner, Akhhlāt, in: Peri Bearman, Thierry Bianquis, C. Edmund Bosworth, Emeri van Donzel, Wolfhart P. Heinrichs (eds), Encyclopaedia of Islam. Second Edition. Accessed on 1 April 2020: dx.doi.org/10.1163/1573-3912_islam_ COM_0036.

Morgan, D.O., Āqā, Encyclopaedia Iranica. Accessed on 26 April 2020: www.iranicaonline. org/articles/aqa-or-aca.

Musalı, Namık, Safevî Kaynaklarına Göre I. Şah Tahmasp ve Kanunî Sultan Süleyman Dönemi'nde Ahlat ve Çevresinde Safevî-Osmanlı Savaşları, Akademik Tarih ve Düşünce Dergisi 2 (2015) 16-31.

Nāṣir-i Khusraw, Book of Travels (Safarnāma), translated from Persian by W. M. Thackston Jr. (Albany, 1986).

Önkal, Hakkı, Anadolu Selçuklu Türbeleri (Ankara, 2015).

Pancaroğlu, Oya, The mosque-hospital complex of Divriği: A history of relations and transitions, Anadolu ve Çevresinde Ortaçağ 3 (2009) 169-198.

Pancaroğlu, Oya, Devotion, hospitality and architecture in medieval Anatolia, Studia Islamica 108 (2013), 48-81.

Peacock, A. C. S., Georgia and the Anatolian Turks in the 12th and 13th centuries, Anatolian Studies 56 (2006) 127-46.

Pfeiffer, Judith, Reflections on a >double rapprochement:: Conversion to Islam among the Mongol elite during the early Ilkhanate, in: Linda Komaroff (ed.), The Legacy of Genghis Khan (Leiden, 2006) 369-389.

Pogossian, Zarouie, Women, identity, and power: A review essay of Antony Eastmond, Tamta's World, Al-'Ușūr al-Wusțā 27 (2019) 233-266.

Prazniak, Roxann, Ilkhanid Buddhism: Traces of a passage in Eurasian history, Comparative Studies in Society and History 56 (2014) 650-680.

Rashīd al-Dīn, Jami'u't-tawarikh: Compendium of Chronicles. A History of the Mongols, Part 3, translated from Persian by W. M. Thackston, Jr. (Cambridge, MA, 1999).

Sinclair, Thomas A., Eastern Turkey: An Architectural and Archaeological Survey 1 (London, 1987).

Sublet, Jacqueline, La folie de princesse Bint al-Ašraf (un scandale financier sous les Mamelouks Bahris), Bulletin d'études orientales 27 (174) 45-50.

Sümer, Faruk, Ahlat, TDV İslâm Ansiklopedisi 2 (1989). Accessed on 27 October 2021: islamansiklopedisi.org.tr/ahlat\#1.

Sümer, Faruk, Ahlatşahlar, TDV İslâm Ansiklopedisi 2 (1989). Accessed on 27 October 2021: islamansiklopedisi.org.tr/ahlatsahlar.

Sümer, Faruk, Selçuklular Devrinde Doğu Anadolu'da Türk Beylikleri (Ankara, 1990).

Tabak, Nermin, Ahlat Türk Mimarisi (Istanbul, 1972).

Tekin, Rahmi, Türk Tarihinde Ahlat (Ankara, n.d. [2018]).

Thierry, Jean-Michel, Monuments arméniens du Vaspurakan (Paris, 1989).

Thomson, Robert W., The historical compilation of Vardan Arawelc'i, Dumbarton Oaks Papers 43 (1989) 125-226. 
Top, Mehmet, Ahlat Osmanlı Kalesi Üzerine Bir Değerlendirme, in: Oktay Belli (ed.), VI. Uluslararası Van Gölü Havzası Sempozyumu (Istanbul, 2011) 141-151.

Tuncer, Orhan Cezmi, 13. Yüzylla Ait Üç Kümbet, Sanat Tarihi Yillığı 6 (1976) 89-123.

Tuncer, Orhan Cezmi, Anadolu Kümbetleri - 1 - Selçuklu Dönemi (Ankara, 1986).

Turan, Osman, Doğu Anadolu Türk Devletleri Tarihi (sixth reprint) (Istanbul, 2001).

Uluçam, Abdüsselam, Ortaçağ ve Sonrasında Van Gölü Çevresi Mimarlığ - II - Bitlis (Ankara, 2002).

Ünal, Rahmi Hüseyin, Az Bilinen ve Tanınmayan Doğu Anadolu Künbetleri Hakkında Notlar, Vakıflar Dergisi 11 (1978) 121-163.

Yāqūt al-Ḥamawī, Mu’jam al-buldān 2 (Beirut, 1977).

Ylldız, Sara Nur, Post-Mongol pastoral polities in eastern Anatolia during the late Middle Ages, in: Deniz Beyazit and Simon Rettig (eds.), At the Crossroads of Empires: 14th-15th Century Eastern Anatolia. Proceedings of the International Symposium held in Istanbul, 4th-6th May 2007 (Istanbul, 2012) 27-48.

Yllmaz, Ahmet, 413 Numaralı Mufassal Tapu Tahrir Defterine Göre Bitlis Sancağl (1555-56). Unpublished MA thesis (Konya, Selçuk University, 2010).

Zhao, George Qingzhi, Marriage as Political Strategy and Cultural Expression: Mongolian Royal Marriages from World Empire to Yuan Dynasty (New York, 2008).

\section{List of figures}

Figure 1: Map indicating cities mentioned in the text (Source: Google Earth view, 30 September 2019)

Figure 2: Satellite view of Ahlat and environs (Source: Google Earth view, 30 September 2019)

Figure 3: Satellite view marked with Ahlat's medieval citadel and Harabeşehir (Source: Google Earth view, 30 September 2019)

Figure 4: Satellite view marked with locations of the Ilkhanid tomb towers (Source: Google Earth view, 30 September 2019)

Figure 5: Tomb of Şeyh Necmeddin (photo by the author, September 2018)

Figure 6: Hasan Padişah tomb tower, view from the north (photo by the author, September 2018)

Figure 7: Hasan Padişah tomb tower, view from the south (photo by the author, September 2018)

Figure 8: Base of a tomb tower near Hasan Padişah, view showing stairs and entry to crypt constructed in restoration work (photo by the author, September 2018)

Figure 9: Usta Şagirt tomb tower, view from the west (photo by the author, September 2018)

Figure 10: Usta Şagirt tomb tower, view from the south (photo by the author, September 2018)

Figure 11: İki Kubbe tomb towers, view from the north with the Ottoman citadel in the distance (source: Lynch, Armenia, 285)

Figure 12: İki Kubbe tomb towers, view from the north (photo by the author, September 2018) 